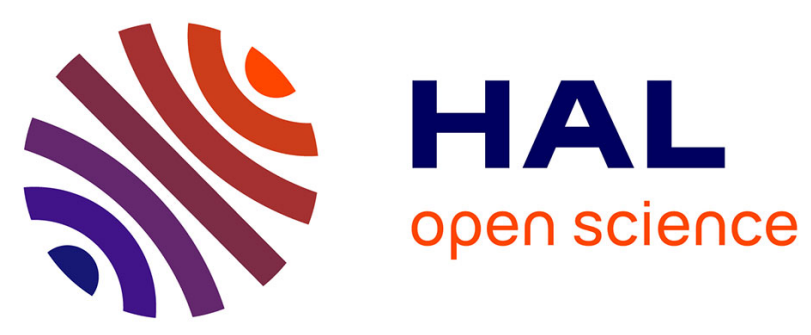

\title{
In search of Pollentia 's southern harbour: Geoarchaeological evidence from the Bay of Alcúdia (Mallorca, Spain)
}

Matthieu Giaime, Christophe Morhange, Miguel Ángel Cau Ontiveros, Joan Fornós, Matteo Vacchi, Nick Marriner

\section{To cite this version:}

Matthieu Giaime, Christophe Morhange, Miguel Ángel Cau Ontiveros, Joan Fornós, Matteo Vacchi, et al.. In search of Pollentia 's southern harbour: Geoarchaeological evidence from the Bay of Alcúdia (Mallorca, Spain). Palaeogeography, Palaeoclimatology, Palaeoecology, 2017, 466, pp.184-201. 10.1016/j.palaeo.2016.11.023 . hal-01760248

\section{HAL Id: hal-01760248 \\ https://hal.science/hal-01760248}

Submitted on 4 Mar 2020

HAL is a multi-disciplinary open access archive for the deposit and dissemination of scientific research documents, whether they are published or not. The documents may come from teaching and research institutions in France or abroad, or from public or private research centers.
L'archive ouverte pluridisciplinaire HAL, est destinée au dépôt et à la diffusion de documents scientifiques de niveau recherche, publiés ou non, émanant des établissements d'enseignement et de recherche français ou étrangers, des laboratoires publics ou privés. 


\section{Accepted Manuscript}

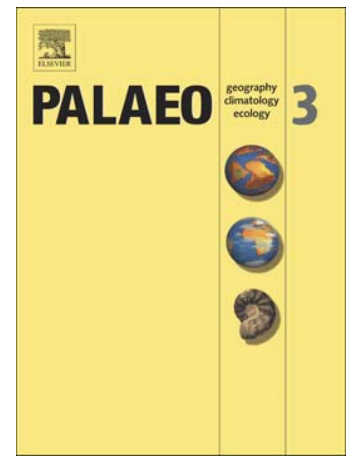

In search of Pollentia's southern harbour: Geoarchaeological evidence from the bay of Alcúdia (Mallorca, Spain)

Matthieu Giaime, Christophe Morhange, Miguel Ángel Cau Ontiveros, Joan J. Fornós, Matteo Vacchi, Nick Marriner

PII:

S0031-0182(16)30722-2

DOI:

doi: 10.1016/j.palaeo.2016.11.023

Reference:

PALAEO 8058

To appear in: $\quad$ Palaeogeography, Palaeoclimatology, Palaeoecology

Received date: 15 July 2016

Revised date: 9 November 2016

Accepted date: 13 November 2016

Please cite this article as: Giaime, Matthieu, Morhange, Christophe, Ontiveros, Miguel Ángel Cau, Fornós, Joan J., Vacchi, Matteo, Marriner, Nick, In search of Pollentia's southern harbour: Geoarchaeological evidence from the bay of Alcúdia (Mallorca, Spain), Palaeogeography, Palaeoclimatology, Palaeoecology (2016), doi: $10.1016 /$ j.palaeo.2016.11.023

This is a PDF file of an unedited manuscript that has been accepted for publication. As a service to our customers we are providing this early version of the manuscript. The manuscript will undergo copyediting, typesetting, and review of the resulting proof before it is published in its final form. Please note that during the production process errors may be discovered which could affect the content, and all legal disclaimers that apply to the journal pertain. 
In search of Pollentia's southern harbour: geoarchaeological evidence from the bay of

\section{Alcúdia (Mallorca, Spain)}

Matthieu Giaime ${ }^{1}$, Christophe Morhange ${ }^{1,2}$, Miguel Ángel Cau Ontiveros ${ }^{3,4,5}$, Joan J. Fornós ${ }^{6}$, Matteo Vacchi ${ }^{1}$, Nick Marriner ${ }^{7}$

${ }^{1}$ Aix Marseille Université, CNRS, CEREGE UMR 7330, Europôle Méditerranéen de l'Arbois, BP 80, 13545 Aix-en-Provence, France.

${ }^{2}$ Institut Universitaire de France, 103 boulevard Saint Michel, 75005 Paris, France.

${ }^{3}$ ICREA, Pg. Lluís Companys 23, 08010 Barcelona, Spain.

4 Equip de Recerca Arqueológica i Arqueomètrica de la Universitat de Barcelona, Departament d'Història i Arqueologia, Facultat de Geografia i Història, c/ Montalegre, 6-8, 08001, Barcelona, Spain.

${ }^{5}$ Joukowsky Institute for Archaeology and the Ancient World, Brown University, Providence, USA.

${ }^{6}$ Universitat de les Illes Balears, Grup de Ciències de la Terra (Geologia i Paleontologia

«Guillem Colom»). Dept. Biologia. Crta Valldemossa km 7.5, 07071 Palma de Mallorca, Spain.

${ }^{7}$ CNRS, Laboratoire Chrono-Environnement UMR6249, Université de Franche-Comté, UFR ST, 16 Route de Gray, 25030 Besançon, France.

\section{$\underline{\text { Keywords }}$}

Ancient harbour, geoarchaeology, palaeogeography, lagoonal harbour, Pollentia, Mallorca, Balearic Archipelago, dredging, sea-level, Holocene, Mediterranean

\section{$\underline{\text { Abstract }}$}


The Roman city of Pollentia was founded on the north-eastern coast of Mallorca (Balearic archipelago) after the Roman conquest of the island in $123 \mathrm{BC}$. There is evidence that the city had two harbours, a small harbour located to the north, whereas the main harbour was located to the south of Pollentia. Our study focuses on the southern harbour, on a coastal plain in proximity to the ancient city. Four sedimentary cores were taken and bio-sedimentological analysis were performed. Here, we describe the palaeogeographical changes in this area, evolving from an open lagoon environment between ca. 3200 and ca. 500 cal. years BC to a semi-enclosed lagoon during Roman times. Progressively, the lagoon became silted and was isolated from the sea by the development of a large sand spit, probably during the second half of the first millennium AD. We also discuss the water depth, linked to the palaeo sea level, which is important in defining the possible ancient harbour location.

\section{Introduction}

The Balearic Archipelago held a strategic position at the centre of maritime shipping routes in the western Mediterranean (Mascaró, 1971; Ruiz de Arbulo, 1990; Guerrero 1993, 2004, 2006; Arnaud, 2005; Carayon, 2008; Colom, 2013) (Fig. 1A). The importance of the Balearics in maritime navigation routes implied the existence of a series of harbours and ports for shelter. In Mallorca, there is evidence that many bays and inlets along the coast provided refuge for the boats crossing the Western Mediterranean during different historical periods. Examples in Fig. 1.B, include Palma and its port of Porto Pí (Cerdà, 1999; Cau, 2004) in the West; Pollença (Cerdà, 2002) and Cala Sant Vicenç (e.g. Nieto et al., 2002; Nieto and Santos 2008) in the North; Porto Colom (VVAA, 2007; Riera and Martín, 2009) and Porto Cristo (Frey, 1970; Manera, 1983; Puig Palerm, 2011, 2015) on the East side; or in the southern part of the island the Colònia de Sant Jordi and the islet of Na Guardis (e.g. Cerdà, 1979, 1980; Guerrero, 1984, 1985, 1987, 1997; Colls, 1987) and the archipelago of Cabrera as attested by 
the shipwrecks found in the area (e.g. Guerrero and Colls, 1982; Colls et al.,1986; Bost et al., 1992; Pons et al., 2001). The coast of Mallorca provides a contrasting and paradoxical environmental context. It is both attractive - with broad bays - and challenging - with the steep cliffs of the Serra de Tramuntana exposed to the northern wind.

The Roman city of Pollentia probably had two ports: one to the south of the city opening onto the Bay of Alcúdia, and the second to the North of the settlement on the southern part of the Bay of Pollença (Fig. 1C). The first bay is cited in Mediaeval documents as Portus Maior while the second is often called Portus Minor (Domingo and Druget, 2004). Concerning the southern part of the city, there is already enough evidence and oral tradition to support the presence of an anchorage in the present port of Alcúdia (Munar and Sastre, 2010) in a marshland area that is presently silted and urbanised.

The main objective of our study is to reconstruct the coastal environments and the palaeogeography of the shoreline of Pollentia since the end of the Holocene marine transgression. More specifically, our research is focused on the environmental potentiality and vulnerability of the site during Roman times in order to ascertain whether or not the environment was favourable for a harbour, south of the ancient city.

\section{Geomorphological context and possible harbour location}

\subsection{Geological setting (Fig. 2)}

The island of Mallorca is composed of four main geomorphological units resulting from a complex geological structure characterised by a set of horst and grabens that trend in a SWNE direction (Ginés et al., 2012). The horst forms the mountain ridges, with the Serra de Tramuntana to the north and the Serres de Llevant to the south and some of the central relief of the island. The central depression, called Es Pla, consists of an extensive area located between the two main ridges. Three stages can be noted in the evolution of the geological 
structure of Mallorca (Sàbat et al., 2011), i) an extensional Mesozoic pre-orogenic stage; ii) a contracting Oligo-Miocene orogenic stage and iii) a relative quiescent mainly extensional, Late Miocene to Recent post-orogenic stage. These tectonic movements, that occurred during the Tertiary period, have created the central hills and the two mountain ridges at the periphery (horst). The rest of the island is formed of Pliocene and Pleistocene deposits undulating on a Miocene carbonate platform (Sàbat et al., 2011). Nowadays, Mallorca is subject to low seismic activity. Instrumental records show that the current seismicity is surficial $(<10 \mathrm{~km}$ depth) and of low magnitude $(\mathrm{mb}<4)$. Only three major seismic events $(\mathrm{MSK}>=\mathrm{VII}-\mathrm{mb}=$ 6.1) are reported in 1660, 1721 and 1851 AD (Silva et al., 2001). At the western Mediterranean basin scale, relative sea-level rose continuously during the whole Holocene. A sudden slowdown began around 7500 years BP and a more pronounced deceleration has occurred during the last 4000 years (Stewart and Morhange, 2009; Vacchi et al., 2016).

\subsection{Coastal geomorphology of Mallorca (Fig. 3) and of the bay of Alcúdia (Fig. 4)}

The Mallorcan coastline is, for the most part, composed of rocky coasts (80\%) (Balaguer, 2005) illustrated by steep rocky coasts on the seaward limits of the two mountain ridges and the low cliffs of the platform of Migjorn. The second type of coast, represented by the large bays of Palma, Pollença and Alcúdia is characteristic of the grabens adjoining the sea, to the west and the east of the island. These provided excellent natural mooring areas for the ancient populations. Alcúdia bay is an important part of the island's coastal lowlands, comprising large sandy beaches largely formed of biogenic sand (Basterretxea et al., 2007). The seabed is covered with Posidonia oceanica meadows extending from depths of 6 to $30 \mathrm{~m}$ (Servera et al., 2006). These seagrasses could be a source of biogenic sediments for the nearby beaches as proposed by Jeudy de Grissac and Boudouresque (1985), De Falco et al. (2003) and Fornós and Ahr (2006). The bay has a structural origin and is delimited by two Mesozoic scarps 
along normal faults (Servera et al., 2009). From a tectonic point of view, Alcúdia bay can be divided in two subsections (Muntaner, 1980; Goy et a., 1997): (i) a stable southern part, characterised by an alternation of sandy beaches and Pliocene rocky coasts (eolianites) surrounding a dune field partially stabilised by a pine forest, while (ii) the northern part is supposed to be subsiding and is formed by a beach-dune system, protecting leeward-side wetlands, in particular the marshy area of s'Albufera (Servera et al., 2009). This north-south distinction is also observed in the hydrodynamics of the bay. Indeed, although sediment transport around the bay is mostly controlled by longshore drift (Servera et al., 2009), there are two sedimentary cells (Fig. 4): (i) the larger northern cell drives sediments northwards; and (ii) the smaller southern cell pushes them to the south. The bay is generally washed by calm waves coming from the north-northeast (32\%), with a significant height of $<1 \mathrm{~m}$ almost three-quarters of the time (Fig. 1C).

The wetland of s'Albufera (ca. 25 square km), situated between the two main ridges (Fig. 4), is a relic of a vast lagoon formed following the Holocene marine transgression (Fornós et al., 1996; Goy et al., 1997). This palaeo-lagoon, separated from the sea by a coastal spit, developed between 6500 and 2400 cal. years BP (Goy et al., 1997), extended up to the Roman city. This wetland is currently fed by the Sant Miquel and Muro streams (up to $0.5 \mathrm{~m}^{3} / \mathrm{s}$ and $0.2 \mathrm{~m}^{3} / \mathrm{s}$ respectively) and by groundwater inputs (up to $0.8-0.95 \mathrm{~m}^{3} / \mathrm{s}$ ) (Canyelles et al., 2003).

\section{Pollentia: historical and archaeological contexts}

The Roman city of Pollentia was founded at the base of a rocky isthmus (Fig. 1C and Fig.2) in a strategic position. It was created following the Roman military intervention of the Balearics (Mallorca and Menorca) by the consul Quintus Caecilius Metellus, later named the Balearicus in $123 \mathrm{BC}$. The city was founded in an area where a previous indigenous 
(Talayotic) settlement was installed. Although the written sources are clear with regards to the foundation of the city in $123 \mathrm{BC}$, from an archaeological point of view, the earliest structures in the Forum date to the 70s/60s BC (e.g., Orfila et al., 1999; Orfila et al., 2006). There was a period of Augustan monumental construction. A major restructuration of the city took place at the end of the second century AD or at the beginning of the third century AD. After a period of trouble at the end of the third century AD, around 270-280, several parts of the city were partially destroyed by a fire well recognised for instance in the insula 1 of tabernae in the forum. However, after this traumatic event, the city continued to be occupied but was transformed during the Late Roman, Vandal (AD 455-534) and Byzantine (AD 534-902/903) periods, probably gradually moving from a Roman Imperial and Pagan city to a Christian one (Cau, 2012). There is also evidence of a Muslim occupation (AD 902/903-1229) in several parts of the city including the forum area (Orfila and Riera, 2002). Overlying the forum, a large necropolis was found that dates to the medieval period (Cau et al., 2016). The medieval city of Alcúdia started to develop on the northern side of the old Roman city and in 1300 it was protected by strong fortifications by order of the king Jaume II of Aragon.

\section{Methods}

\subsection{Biosedimentology}

Our work is based on four continuous cores, between 410 and $453 \mathrm{~cm}$ length, drilled close to the limits of the Roman city (Fig. 5). The coring campaign was undertaken using a mechanical rotary corer and benchmarked relative to MSL using a GPS. Core descriptions (texture, macrofauna, organic remains) and sampling were undertaken during fieldwork. Biosedimentological analyses were undertaken using the methodology detailed in Marriner and Morhange (2007) and Marriner (2009). In the laboratory, the general sediment texture including the coarse fraction $(>2 \mathrm{~mm})$, sand fraction $(50 \mu \mathrm{m}-2 \mathrm{~mm})$ and silty-clay fraction 
$(<50 \mu \mathrm{m})$ was determined by wet sieving and laser granulometry using a Malvern mastersizer. Ostracods were picked from the fraction $>150 \mu \mathrm{m}$ and identified to species level (Athersuch et al., 1989; Lachenal, 2000). Macrofossils $>1 \mathrm{~mm}$ were also identified and assigned to assemblages according to the Mediterranean classification system (D'angelo and Garguilo, 1978; Poppe and Gotto, 1991, 1993; Doneddu and Trainito, 2010). Loss on Ignition (LOI) was used to quantify organic matter and the $\mathrm{CaCO}_{3}$ content of the sedimentary sequences (Bengtsson and Enell, 1986; Heiri et al., 2001; Santisteban et al., 2004).

\subsection{Chronology}

The chronology is based on twenty-three AMS radiocarbon determinations performed at the Poznan Radiocarbon Dating Center (Table. 1). We calibrated the dates using Calib 7.1 (Stuiver and Reimer, 1993) and IntCal13 and Marine13 curves (Reimer et al., 2013). For the marine shells, we used a local $\Delta \mathrm{R}$ of 75.9 with an uncertainty of 40.5 , based on the average of ten published dates of marine shells from around the site (http://calib.qub.ac.uk/marine/). We constructed an age model using the dedicated R-code Clam (Blaauw, 2010), which uses repeated random sampling of the dates' calibrated distributions to derive a robust age-depth model.

\subsection{Statistics}

Principal components analyses (PCA) were performed to test the ordination of samples by assessing major changes in palaeoenvironmental proxies. In this statistical analysis, faunal records (ostracod ecology, mollusc ecology) were included for each core. Ostracods and molluscs have been grouped according to species ecology. PCA ordination was chosen because it is a non-parametric method that extracts the most important information from complex datasets (e.g. Kaniewski et al., 2008, 2015; Marriner et al., 2014). Most of the 
variance is accounted for by the first PCA-Axis, hence, the PCA-Axis1 scores were plotted on a linear depth-scale for each core. The statistical analyses were performed using the paleontological statistics software PAST (Version 2.14, Hammer et al., 2001).

\subsection{Modelling sea-level position during the Roman period}

The sea-level position during the Roman period in the Balearic archipelago is essential in reconstructing the water-column depth of the harbour basin. Presently, there is a paucity of archaeological and geological data constraining late Holocene (i.e. last 4.0 ka) RSL in the Balearic archipelago. For this reason, we used numerical models to predict the RSL position during the Roman period. We used an improved version of the open source code SELEN (Spada and Stocchi, 2007) that, at the western Mediterranean scale, has been shown to be robust in predicting RSL position during the Holocene (Vacchi et al., 2016). For the purposes of this study, we used the ICE-5G glacio-isotatic adjustment (GIA) model of Peltier (2004) to predict a nominal RSL curve, based on a three-layer approximation of the multi-layered viscosity profile VM2. To account for the uncertainties in the viscosity profiles (see Vacchi et al., 2016), we performed further runs varying the viscosity profiles in each layer within a reasonable range: the minimum and maximum viscosity. At the western Mediterranean scale, the palaeo sea-level position is typically constrained between the nominal and the minimal RSL curves predicted by the ICE-5G (VM2) model (Vacchi et al., 2016).

\section{Results}

The soundings undertaken on the coastal plain have elucidated the stratigraphy. We first present the litho- and biostratigraphic results obtained for the core POL6/b because it is the most representative of the lagoon's evolution and because this core reaches the pretransgressive substratum composed of Miocene marls. Then, we compare the evolution of the 
palaeo-lagoon recorded in the different cores, using a PCA. The synthetic results for the core POL3 are presented in order to highlight differences with the reference core POL6/b. The study of POL10 highlights the specificity of facies on the lagoon shore.

\subsection{General evolution of the lagoon}

\subsubsection{Stratigraphic evolution of the lagoon recorded in core POL6/b (Fig. 6 and Fig. 7)}

The depositional facies have been divided into units, A-C for the core POL6/b, and are described from oldest to youngest. The base of the core, between 445 and $420 \mathrm{~cm}$ depth is composed of middle Miocene marls incorporating silts and gravels.

Unit A: Open lagoon between 3200 and ca. 1200 cal. yr BC

Unit A, located between $420 \mathrm{~cm}$ and $220 \mathrm{~cm}$ depth, is characterized by poorly sorted siltysands (mode $\approx 150 \mu \mathrm{m}$ and sorting values between 1.2 and 1.6). The coarse fraction, representing $15 \%$ of the total weight of the sediment, is only composed of shells and plant remains. The organic matter content is between $3 \%$ and $11 \%$ and the sediments are very calcareous $\left(\mathrm{CaCO}_{3}=73 \%\right)$. A radiocarbon date obtained from a marine shell (Loripes lacteus; $400 \mathrm{~cm}$ depth) indicates that this unit was deposited beginning around $4900 \pm 35 \mathrm{yr}$ BP (3350 - 3035 cal. yr BC; Poz-69457). The age of the top of the unit is unclear due to two age reversals. Nonetheless, we believe that the date of $3395 \pm 35$ yr BP (1375 - 1054 cal. yr BC; Poz-69099) can be accepted because it is conventional that in such instances, the youngest age is the most reliable.

The base of the unit is characterised by an important species richness. More than 100 individuals (gastropods or bivalves) were found in each sample (in around $20 \mathrm{~g}$ of sediment). The lagoonal assemblage is dominant (50\%). It is composed of the group Hydrobia spp. associated with other species such as Abra segmentum, Cerastoderma glaucum, Loripes lacteus and Parvicardium exiguum. The remaining species are specimens living on marine 
upper-muddy sand substratum (10\%) like Cerithium vulgatum and Lucinella divaricata or in infratidal sands $(\approx 20 \%)$ such as Alvania spp., Bittium reticulatum, or Rissoa ventricosta. Some species living on marine rocky substratums are also present in the unit (Cythara sp., Gibbula albida and Gibbula varia).

The ostracod ecological groups are similar to those of the macrofossils. The lagoonal (Cyprideis torosa and Cytherois fischeri) and marine lagoonal (Loxoconcha elliptica and Xestoleberis spp.) species are dominant with respectively $31 \%$ and $49 \%$ of the total assemblages. Coastal species, dominated by Leptocythere psammophila, represent $14 \%$ of the assemblage. Marine species are sporadically represented by some individuals of Callistocythere sp. or Hiltermannicythere emaciata. This association of species, based on both the macrofauna and ostracod assemblages, is typical of an open lagoon (Salel et al., 2016).

Unit B: Gradual transition/closure of the lagoon around the beginning of the present era Unit B, situated between 220 and $160 \mathrm{~cm}$ depth, is characterised by an increase in the sediment grain size (the mode doubles to $200 \mu \mathrm{m}$ ). The coarse fraction, that represents $7 \%$ of the total weight, is composed of shell debris and small sub-rounded gravels. The sediment of the unit is mostly composed of $\mathrm{CaCO}_{3}(>70 \%)$. The quantity of organic matter decreases relative to the previous unit and represents just $2 \%$.

In this unit, the relative abundance of the lagoonal assemblage increases considerably. It accounts for $45 \%$ of the total assemblage at the base of the unit, increasing to more than $95 \%$ of the individuals at the top. This domination of the lagoonal species is accompanied by an important decrease in species diversity, which is typical of partially closed lagoon contexts. In fact, the macrofauna is almost monospecific, characterised by Hydrobia spp. Coastal species dominated by Rissoa ventricosa and Bittium reticulatum are present at the base of the unit, 
then they disappear. Like in the previous unit, the ostracofauna closely mirrors the evolution of the macrofauna. Progressively, a monospecific environment, comprising $C$. torosa, appears.

The presence of ceramics, probably Roman, in this unit, shows that this facies was contemporaneous with Pollentia. In addition, some trenches opened in the port area in 2015 reveal the presence of a larger number of Roman ceramics (not studied in depth yet) immediately near the core POL6/b.

Unit C: closed lagoon after the $6^{\text {th }}$ century AD.

Unit C, between 160 and $130 \mathrm{~cm}$ depth, is a silty-sand unit. The mode, starting near $400 \mu \mathrm{m}$ at the base of the unit decreases to less than $100 \mu \mathrm{m}$ at the top and the sediment is increasingly less well sorted. The coarse fraction, most important at the top of the unit, is again composed of shell debris. A radiocarbon date, performed on a Cerastoderma glaucum shell at the base of the unit, yielded an age of $1840 \pm 30 \mathrm{BP}(573-663$ cal. yr AD; Poz-69098). A monospecific assemblage comprising Hydrobia spp. prevails. A few individuals of Cerastoderma glaucum (lagoonal) and Bittium reticulatum (coastal) are however present in the unit. The ostracod assemblage is also monospecific, with Cyprideis torosa throughout the whole unit. There are a few species that prefer fresh to oligohaline waters (Darwinula stevensoni, Ilyocypris gibba). The closure of the lagoon is further underscored by a decrease in the faunal density. A similar trend was identified by Flaux et al. (2013) in the Holocene stratigraphy of the Maryut lagoon (Egypt). Using strontium isotopes in Cyprideis torosa shells, they demonstrated that the abundance of lagoonal species was positively correlated with marine inputs into the lagoon's water budget. According to the Mediterranean classification of paralic environments by Guelorguet and Perthuisot (1983), this biofacies is consistent with protected conditions, with limited seawater renewal. 
The upper $130 \mathrm{~cm}$ of the core is composed of coarse sediments from modern filling of the lagoon for health and sanitary reasons during the 1960s.

\subsubsection{Comparison of the cores POL3, POL6/b and POL9 (Fig. 8 and Fig. 10)}

The results of the Principal Components Analyses (PCA) show the gradual closure of the lagoon. The assemblages are the same for the three cores and are detailed for the core POL6/b (Fig. 9). The core shows positive scores for the lagoonal species which are correlated with a closure of the lagoon. Conversely, species preferring marine waters and less variability in salinity, present negative scores consonant with an open lagoon exposed to marine influence. The PCA of core POL6/b is dominated by negative scores in unit A, consistent with an open lagoon phase. Subsequently, we observe an increase in the scores linked to the closure of the lagoon (Unit B). Finally, a stabilisation of the PCA scores translates the transition to a semienclosed lagoon (Unit C).

The results highlight the progressive closure of the lagoon that started before the present era (Fig. 8). The core POL 3 shows that this phenomenon started between $3200 \pm 30$ yr BP (1521 - 1417 cal yr BC; Poz-69460) and $2425 \pm 30$ yr BP (162 cal yr BC - 101 cal yr AD; Poz72246).

\subsection{Core POL3: harbour basin core (Fig. 10 and Fig. 11)}

As highlighted by the results of the PCA, the biostratigraphic results of core POL3 show the same general palaeoenvironmental evolution of the lagoon. The same units as POL6/b have been identified (Fig. 10). The silty-sand unit (Unit A), deposited between ca. $2000 \mathrm{yr}$ cal. BC and ca. $1470 \mathrm{yr}$ cal. BC is the open lagoon stage, characterised by the same assemblages as core POL6/b (Unit A) but with a lower proportion of lagoonal species. The sharp transition is also clear in this core, especially in the ostracod record but occurs at a greater depth than in 
POL6/b (Unit B) (Fig. 8). The "lagoonal unit" is thicker in POL3 $(\approx 100 \mathrm{~cm})$ than in POL6/b $(\approx 70 \mathrm{~cm})$. Unit B's faunal record is similar, characterised by the abundance of Cyprideis torosa and Hydrobia spp in the upper part. In this unit, a sub-unit formed by finer sediment bearing shells is observed (silts and clay $>50 \%$; Fig. 10 and Fig. 11). The closure of the lagoon is translated by a decrease in the molluscan species diversity and the absence of ostracods after 841-1092 cal. yr AD in POL3 (529 - 746 cal. yr AD in POL6/b).

From a geoarchaeological perspective, the association of bio-sedimentological data with chronological results allows us to divide the stratigraphic sequence of the core into three general units described in Marriner and Morhange (2006) as the "Ancient Harbour Parasequence" (AHP) (Fig. 11). Within this framework, the silty-sand unit at the base of the core corresponds to the pre-Roman harbour phase, identified as an open lagoon environment increasingly protected, from a faunal perspective, by the growth of a sand spit. The silt unit that begins to develop at the onset of the present era is identified as the harbour phase. It is followed by the harbour abandonment phase, consistent with a shallow lagoon gradually disconnected from the sea. This succession constitutes a classic progradational sequence.

The strata formed by fine-grained sediments only appear in this core, the others being characterised by sand at the same depth. Three radiocarbon dates at the base of this unit yielded an age between ca. 30 cal. yr BC and 960 cal. yr AD. A gap exists between the dates obtained in the cores POL3 and POL6/b. In fact, at the same depth, POL3 is dated to 162 cal. yr BC - 101 cal. yr AD at $139 \mathrm{~cm}$ depth b.s.l. and POL6/b is at least a thousand years older and displays several age reversals (Fig. 8). We will discuss this finding in section 6.1.3.

\subsubsection{Results of core POL10: a marginal lagoonal environment}

Core POL10 presents chrono-stratigraphic differences when compared to the cores taken from the palaeo-lagoon. It provides specific information concerning the evolution of the eastern 
shore of the lagoon during Roman times. For core POL10, the facies have been divided into units A to D and are described from oldest to youngest (Fig. 5, 12 and 13). This core is then presented alone, with no direct connection with the cores taken from the palaeo-lagoon.

Unit A: Monospecific marginal lagoon facies before 3400 cal. yr BC

Unit $\mathrm{A}$, dated in its centre to $5060 \pm 30 \mathrm{yr} \mathrm{BP}(\approx 3954-3791$ cal. yr BC; Poz-69473) comprises very poorly sorted fine sediments (sorting $>2$ and mode $<50 \mu \mathrm{m}$ ); silts and clays represent around $80 \%$ of the total weight of sediment. The proportion of $\mathrm{CaCO}_{3}$ is lower than $10 \%$ and the quantity of organic matter is negligible. The depth of this unit is between 370 and $425 \mathrm{~cm}(200-255 \mathrm{~cm}$ below present sea level), this fact shows that the depositional environment was probably situated in an area of higher elevation because it is not clearly linked to the lagoon at that time. In this unit, the fauna is mostly composed of lagoonal species $($ molluscs $=$ Hydrobia spp. $(80 \%)$; ostracods $=$ Cyprideis torosa $(90 \%)$ ). At the base of the unit, a few individuals of the mollusc Myosotella myosotis, that can support periods emerged, testify to the proximity of the shore. In this unit, the molluscan density is low (2) as is the ostracod density ( $\approx 15$ valves $/ 20$ grams). This unit is interpreted as a protected brackish water body with probable episodic seawater input, possibly during storms and high-swell episodes.

Unit B: Coastal sand deposition between 3400 and 2500 cal. yr BC

This unit develops between ca. $4570 \pm 30$ yr BP (3493 - 3110 cal. yr BC; Poz-69472) and ca. $4395 \pm 30$ yr BP (2655 - 2328 cal. yr BC; Poz-69470). The unit differs from the previous one in terms of the sediment texture. In this unit the sediment is coarser (two peaks in the mode at $1200 \mu \mathrm{m}$ ) and better sorted (sorting $\approx 1.4$ ). The coarse fraction represents $50 \%$ of the total sediment in the centre although the relative proportion of the sand fraction is not greater than 
in unit A. The coarse fraction is essentially composed of shells, mostly broken, as confirmed by the important increase in the $\mathrm{CaCO}_{3}$ values. Regarding the fauna, there is an important increase in the diversity of the assemblages associated with an increase in the faunal density. Moreover, it is in this unit that the molluscs and the ostracods are the most abundant and varied. Seven ostracod species were found with an average faunal density of 1300 valves per 20 grams of sediment. The ostracods show assemblages from lagoonal (56\%), marine lagoonal (42\%) and from coastal environments (2\%). This combination of species is also visible in the macrofaunal assemblage and reflects the same type of environment. We interpret this unit as being coastal sands deposited close to sea level during the third millennium $\mathrm{BC}$ at the end of the littoral cell.

Unit C: Semi-enclosed lagoon between ca. 2500 cal. yr BC and 0 cal. yr AD

Contrary to the other cores, the texture of this unit is very fine (mode $<100 \mu \mathrm{m}$ ). Silts and clays represent more than $75 \%$ of the total sediment. Fine sands represent around $80 \%$ of the total sand fraction. The faunal assemblage of this unit is typical of a very shallow water body disconnected from the main lagoon. The ostracods are dominated by Cyprideis torosa and a few individuals of Sarcypridopsis aculeata. The macrofauna is composed of Hydrobia spp. and some specimens of Myosotella myosotis. This unit probably reflects the inland part of the lagoon.

\section{Unit D: Marshland from Roman times onwards}

The sedimentary texture of this unit is the same as in unit C. Fine sands represent $65 \%$ of the total sand fraction. The molluscan assemblage is dominated by the snail species Myosotella myositis. This taxon is well adapted to supratidal coastal fringes and can tolerate fresh to polyhaline waters. The association of this mollusc with the ostracod species Sarcypridopsis 
aculeata reveals an environment that is not permanently inundated. A radiocarbon date of a Myosotella myosotis shell in this unit yielded an age of $1725 \pm 30 \mathrm{yr}$ BP (245 - 388 cal. yr $\mathrm{AD}$; Poz-72249). ${ }^{14} \mathrm{C}$ dating on terrestrial shells is not commonly used because large taxa are known to incorporate dead carbon from carbonate rocks when building their shells. This phenomenon can create age offsets of up to 3000 years (Pigati et al., 2010). The same authors suggest, however, that the fossil shells could sometimes yield ${ }^{14} \mathrm{C}$ ages statistically indistinguishable from ${ }^{14} \mathrm{C}$ ages of well-preserved plant macrofossils from the same stratum. On this basis, we can only assume that this layer is younger than 245 - 388 cal. yr AD. This part of the coastal plain was largely silted in Roman times. Presence of these species also attests to freshwater inputs. These inputs could be linked to the proximity of a spring or to the everyday use of inhabitants possibly released in the lagoon by a sewer.

\section{Discussion}

6.1. The lagoon 2000 years ago: geomorphological and biological evidence for a possible harbour area

After the conquest of Mallorca in $123 \mathrm{BC}$, the first Romans found a coastal lagoon suitable for a harbour in the northern part of the bay of Alcúdia. This area was protected from the prevailing winds and waves, coming from the North, by the rocky promontory of Cap des Pinar. Part of the harbour activities of Roman Pollentia may have taken place inside the palaeo-lagoon identified in our geoarchaeological drillings. This harbour environment shows features common to many harbours in lagoonal contexts that generally evolved towards the complete closure of the lagoonal water body over time (regressive sequence sensu Morhange et al., 2015). It shares some geomorphological traits with the ancient lagoon of Kition in Cyprus, that hosted the Hellenistic port of the city. Morhange et al. (2000) showed that the leaky lagoon was partially closed by a gravel spit and used as a military harbour (Bamboula) 
for Kition, capital of a Phoenician kingdom, during the first millennium BC. Another harbour was possibly located in the same context to the northwest at Kathari (Bony et al., 2016). The lagoonal harbour of Cumae-Licola, situated down-drift from the Volturno river was a protected mooring area during Archaic times. The combined formation of offshore sand bars, rendering access to the lagoon difficult, and of silting, explain why it was abandoned in early Roman times (Stefaniuk et al., 2003; Stefaniuk and Morhange, 2010). The specificity of lagoonal harbours compared to artificial harbours (Marriner and Morhange, 2006), is that lagoons do not show important anthropogenic impacts in the sedimentary facies due to the absence, in most cases, of protective harbour structures.

\subsubsection{Spatial extent of the lagoon}

Our research has highlighted that this lagoon, separated from the sea by a coastal sand spit, extended to the foot of the Roman city (Fig. 14). Several archaeological test pits made in the area in 2015 (Cau et al., 2015) show the presence of several finds, including some walls or their foundations, a human incineration contained in an italic cooking pot (see Fig. 14, labelled as necropolis) and several Roman ceramic finds mainly amphorae. The ceramics were encrusted with marine organisms showing that sea water was present near this edifice. Another Roman structure, probably linked to the exploitation of the lagoon, was found in the north-east and confirms its limit in this direction, as shown by the presence of a coastal marsh in the core POL10 that translates the shoreline of the lagoon.

Such a morphology is typical of coastal lagoons used as harbours (Morhange et al., 2015). A map drawn in 1851 (Fig. 15), representing the northern shore of the bay of Alcúdia shows that this morphology persisted in part until the $19^{\text {th }}$ century before the lagoon was drained and artificialized a century later. During Roman times, the lagoon that hosted the harbour of Pollentia was connected to the sea by a channel probably south of our drilled zone because of 
the low density of coastal species discovered in the faunal assemblage of the lagoonal unit. According to the classification of Kjerfve (1986), this lagoon could correspond to a restricted lagoon connected by the modern channel linking the pond "Estany dels Ponts" to the sea, identified on the 1851 map (Fig. 15).

The northern shore of the lagoon was situated near the theatre, at the foot of a rocky coast formed by Quaternary aeolianites discovered during archaeological excavations near this zone. The proximity between the lagoon and the city is an essential aspect in the choice of harbour installations. During Antiquity, coastal lagoons close to settlements were, in many cases, chosen as natural anchorages by coastal populations because of their favourable environmental conditions, such as Orgame on the margin of the Danube delta in present-day Romania (Bony et al., 2015), in order to avoid carrying goods over long distances and for the defence of the harbour.

\subsubsection{Evolution of the harbour's water column (POL3)}

As demonstrated by Boetto (2010), the nautical dimensions of a harbour basin, in terms of its volume and geometry, are essential. Thus it is necessary to consider the accessibility of docks, and boat traffic in the different areas of the harbour (Salomon et al., 2016). The relative sealevel (RSL) position 2000 years ago is crucial because, together with the sedimentary budget, it determines the water depth of the lagoon and consequently the thresholds for the accessibility of ships. There is a paucity of geological sea-level data constraining the RSL position in Roman times in the Balearic Islands. Following the protocol proposed by Vacchi et al., (2016), our lagoonal data indicate that the sea-level position was within $1 \mathrm{~m}$ above $1.39 \mathrm{~m}$ at $\sim 30 \mathrm{BC}$ cal. yr and above $-1.29 \mathrm{~m}$ at $\sim 380 \mathrm{cal}$. yr AD. These values match estimates predicted using the ICE-5G (VM2) GIA model (Spada and Stocchi, 2007; see section 4) 
which constrain the RSL position during Roman times to $-35 \pm 15 \mathrm{~cm}$ below the present MSL (Fig. 16).

According to these data, the reconstructed water column in the harbour basin (core POL3;

Fig. 11) can thus be estimated at $100 \pm 15 \mathrm{~cm}$ in the $1^{\text {st }}$ century AD. The core POL 3 was drilled in proximity to the lagoon's shoreline, so it can be reasonably assumed that the depth increases seawards. Such a water column is sufficient for a harbour basin, allowing the navigation of ships (Section 6.2).

\subsubsection{Hiatus in the sedimentary record of POL3}

The comparison of cores POL3 and POL6/b highlights chronological gaps. For POL3, the chronology obtained is consistent, age increases with depth. The unit identified as the "harbour facies", sensu Marriner et Morhang (2006), is dated between 162 cal. yr BC to 101 cal. yr AD and 841 to 1092 cal. yr AD (Fig. 11). However, an important chronological shift occurred between the top of the "pre-harbour" unit (1521 - 1417 cal. yr BC) and the bottom of the harbour unit (162 cal. yr BC and 101 cal. yr AD). Furthermore, the top of the open lagoon unit (Unit A) of core POL6/b presents important age reversals (Fig. 8).

The chronological gap encountered in POL3 could be explained by a sedimentary hiatus. One explanation for this hiatus is ancient dredging. Such harbour maintenance practises have, for example, been identified in several ancient harbours in the Mediterranean (Morhange and Marriner, 2010b), in Marseille (Morhange et al., 2003), in Naples (Giampaola et al., 2004) and in Tyre (Marriner and Morhange, 2006b). Calculation of sedimentation rates for POL3 (Fig. 11) shows important differences between the pre-harbour unit and the harbour unit. In fact, the sedimentation rate obtained for the pre-harbour facies $\left(<2.5 \mathrm{~mm}\right.$. $\left.\mathrm{yr}^{-1}\right)$ is the highest rate encountered in the core. The base of the unit identified as the harbour phase, only recovered in POL3, is dated to around 30 cal. yr BC consistent with the city's foundation. 
Furthermore, the sedimentation rate shows limited sediment accumulation in this unit (sedimentation rate $\approx 0.17 \mathrm{~mm} . \mathrm{yr}^{-1}$ ) which could indicate sediment removal from the harbour basin. If dredging practises took place in the lagoon, they probably began in the first century $\mathrm{BC}$ and could explain the hiatus recorded between the end of the pre-harbour unit and the harbour unit, such as for the harbour of Lechaion (Corinthos gulf) which was dug into the loose substrate during the Iron Age (Stiros et al., 1996; Morhange et al., 2012; Mourtzas et al., 2014). In this case, the harbour could also present similarities with the Greek harbour of Naples, where excavations in the ancient harbour basin have shown that the harbour bottom was completely reshaped by extensive dredging between the fourth and the second centuries BC (Giampaola et al., 2004; Carsana et al., 2009). Dredging activities may have caused the re-suspension of sediments and could explain the age reversals in POL6/b.

Regarding these results, we can estimate that the harbour could have been used between ca. 30 cal. yr BC (162 cal. yr BC - 101 cal. yr AD) and 966 cal. yr AD (841 - 1092 cal. yr AD) if we take into account the date obtained from the core POL3 (Table. 1). But the date of the abandonment of the harbour could be shortened to ca. 637 cal. yr AD (529 - 746 cal. yr AD) because it is the date of the lagoon closure recorded in the core POL6/b.

\subsection{Navigation inside the lagoon}

As demonstrated by the estimates of the lagoon's water column, the circulation of large ships linked to interregional trade would have been difficult within the lagoon during Roman times. Based on the work of Charlin et al. (1978), Boetto (2008, 2010), Carre and Roman (2008) and Poveda (2012), the harbour basin could however accommodate ships with a deadweight of around 20 tons for a draught of ca. 1m (Table. 2). Shipwrecks excavated in Naples (Napoli A and B) and Portus near Rome (Fiumicino 1), are associated with coastal navigation and were used as lighter vessels in order to carry goods transported by large commercial vessels 
(Boetto, 2008, 2010). Our data assume that the depth of the lagoon was adequate for such boats and even for larger ones in other parts of the lagoon.

A large amount of archaeological remains, located near the Alcanada islet (Fig. 1) and in the present commercial port of Alcúdia (Munar and Sastre, 2010), allows us to hypothesize a deep water anchorage or outer harbour for large commercial vessels. Such a scenario has been envisaged for the harbour of Sidon (Lebanon), where the outer harbour was located on the leeward side of Zire island, 800 meters from the inner harbour (Frost, 1973; Carayon, 2003; Marriner et al., 2006). Goods could be safely unloaded and transported to the mainland port by smaller ships such as lighters. An important source of freshwater in the immediate vicinity of the islet of Alcanada (Gràcia et al., 2001) was then available for sailors, making this area a possible mooring zone for transiting ships.

Conclusions and perspectives

Infilled lagoonal harbours in deltaic contexts are the best represented type of lagoonal harbours (see Morhange et al, 2015, 2016). The lagoon of Pollentia, situated on the margin of the vast palaeo-lagoon of s'Albufera, has undergone the same geomorphological evolution as deltaic lagoons. In fact, sediment supply and low accommodation space invariably leads to the infilling of these basins during historical times due to the stabilisation of sea level during the last 7000 years (Stewart and Morhange, 2009; Vacchi et al., 2016) and coastal progradation driven by sediment supply at base-level (Stanley and Warne, 1994; Anthony et al., 2014).

Our geoarchaeological work reveals the presence of a lagoon near the Roman city of Pollentia. This water body, separated from the sea by a sand spit accomodating constructions of Roman age, was well protected from winds and waves and could accommodate shallowdraft vessels, which were commonly used at this time. The other boats, larger and probably in 
transit, had the possibility to anchor offshore in a quiescent area close to the Alcanada islet. We assume that human activities, and possible harbour activities, took place around the area where our core POL3 was drilled due to possible evidence for dredging around 2000 years ago. Such lagoonal harbours, situated in a naturally protected basin made possible, by means of reduced infrastructure (landing stage) and the possible beaching of small boats, a logical development of harbour activities.

Further investigations in Pollentia should consider the extension of the lagoon to the south of the bay in order to better understand the geomorphology of the water body and to try to locate an area where the lagoon was less confined, in order to find the possible location of the channel which permitted access to the lagoon. Geophysics could be an interesting tool for a better cartography of the ancient lagoon and to help pinpoint the location of possible harbour structures. These results should also be validated by further archaeological excavations.

\section{Acknowledgements}

This work has been carried out thanks to the support of the Labex OT-Med (ANR-11-LABX0061) and of the A*MIDEX project ( $\mathrm{n}^{\circ}$ ANR-11-IDEX-0001-02), funded by the « Investissements d'Avenir » French Government program, managed by the French National Research Agency (ANR). We are also grateful to the Consorci de la ciutat romana the Pol·lèntia and the Ministerio de Educación, Cultura y Deportes de España, for financial aid in order to carry out the coring campaign. These activities are part of the archaeological investigations of Pollentia headed by M.A. Cau and E. Chávez. In addition, this research is part of the activities of the Equip de Recerca Arqueològica i Arqueomètrica de la Universitat de Barcelona (ERAAUB), Consolidated Group (2014 SGR 845), supported by the Comissionat per a Universitats i Recerca del DIUE de la Generalitat de Catalunya. Part of 
the sedimentology analyses were performed at the Geology Lab of the Universitat de les Illes Balears under the funding of a MINECO grant, CGL2013-48441-P to J.J, Fornós.

We thank the IUF, the Eccorev federation and the sedimentology laboratory of the CEREGE (D. Delanghe) for co-funding of the binocular microscope Leica MZ125. The authors thank C. Flaux for his interesting suggestions on an earlier version of the manuscript.

T. Corrège (Editor in Chief) and the two anonymous reviewers are thanked for their valuable comments that helped us to improve an earlier version of this manuscript.

\section{References}

Anthony, E.-J., Marriner, N., Morhange, C. (2014). Human influence and the changing geomorphology of Mediterranean deltas and coasts over the last 6000 years: from progradation to destruction phase ? Earth-Science Reviews, 139, 336-361.

Arnaud, P. (2005). Les routes de la navigation antique : itinéraires en Méditerranée. Paris, Errance, 248 p.

Athersuch, J., Horne, D.J., Whittaker, J.E. (1989). Marine and Brackish Water Ostracods (Superfamilies Cypridacea et Cytheracea): Keys et Notes for the Identification of the Species. New York, Brill Archive (Ed.).

Balaguer, P. (2005). Tipus I evolucio de les costes rocoses de Mallorca. Unpublished doctoral dissertation. Departament de Ciències de la Terra, Universitat de les Illes Balears, 373 p.

Basterretxea, G., Orfila, A., Jordi, A., Fornós, J.J., Tintoré, J. (2007). Evaluation of a small volume renourishment strategy on a narrow Mediterranean beach. Geomorphology, 88(1), $139-$

151.

Bengtsson, L., Enell, M. (1986). Chemical analysis. In Berglund, B.E. (Ed.), Handbook of

Holocene Palaeoecology and Palaeohydrology, Wiley, Chichester, 423-445.

Blaauw, M. (2010). Methods and code for 'classical' age-modelling of radiocarbon sequences. 
Quaternary Geochronology, 5, 512-518.

Boetto, G. (2008). L'épave de l'Antiquité tardive Fiumicino 1 : analyse de la structure et étude fonctionnelle. Archaeonautica, 15, 29-62.

Boetto, G. (2010). Le port vu de la mer : l'apport de l'archéologie navale à l'étude des ports antiques. Bollettino di Archeologia online, 112-128.

Bony, G. (2013). Contraintes et Potentialités de quelques sites portuaires antiques de Mediterranée (Fréjus, Ampurias, Kition, Orgame, Istanbul), Unpublished doctoral dissertation, Aix-Marseille Université.

Bony, G., Morhange, C., Marriner, N., Baralis, A., Kaniewski, D., Rossignol, I., Lungu, V. (2015). History and influence of the Danube delta lobes on the evolution of the ancient harbour of Orgame (Dobrogea, Romania), Journal of Archaeological Sciences, 61, 186-203.

Bost, J. P., Campo, M., Colls, D., Guerrero, V. M., Mayet, F. (1992). L’Épave Cabrera III (Majorque). Échanges commerciaux et circuits monétaires au milieu du IIIe siècle après Jésus-Christ. Paris, Publications du Centre Pierre Paris, 23.

Canyelles, M., Pujals, M., Ripoll, S., Segui, A. (2003). Sa Pobla. La gent, el medi, la història. Sa Pobla, Ajuntament de sa Pobla.

Carayon, N. (2003). L'île de Ziré à Saida : Nouvelles données archéologiques. Archaeology \& History in Lebanon, 18, 95-114.

Carayon, N. (2008). Les ports phéniciens et puniques. Géomorphologie et infrastructures. Unpublished doctoral dissertation, Université Strasboug II - Marc Bloch.

Carre, M.B., Roman, R. (2008). Hypothèse de restitution d'un navire à dolia : la construction d'une maquette. Archaeonautica, 15, 176-192.

Carsana, V., Febbraro, S., Giampaola, D., Guastaferro, C., Irollo, G., Ruello, M.-R. (2009). Evoluzione del paesaggio costiero tra Parthenope e Neapolis. Méditerranée, 112, 14-22

Charlin, G., Gassend, J.M., Lequément, R. (1978). L'épave antique de la baie de Cavalière 
(Le Lavandou, Var). Archaeonautica, 2, 9-93.

Cau, M.A. (2004). La ciutat romana de Palma: hipòtesis sobre el seu traçat urbà i restes arqueològiques, in Orfila, M. and Cau, M.A., Les ciutats romanes del llevant peninsular i les Illes Balears. Pòrtic, Barcelona, 191-237.

Cau, M.A. (2012). Urban Change in Late Antiquity in the Balearic Islands. In Christie, N., and Augenti, A. (eds.), Vrbes Extinctae. Approaches to archaeologies of abandoned classical towns, Ashgate Publishing Company, Aldershot-Burlington, 115-144.

Cau, M.À., Chávez-Álvarez, E, Vallori Márquez, B., Munar Llabrés, S. (2015). Estudi arqueològic del port de la ciutat romana de Pollentia i l'Albufera d'Alcúdia. sector AS6 de les NNSS d'Alcúdia (Mallorca). Informe preliminar. Unpublished manuscript.

Cau, M.Á., Van Strydonck, M., Boudin, M., Mas Florit, C., Mestres, J.S., Cardona, F., Chávez, Ma.E., Orfila, M. (2016). Christians in a Muslim World? Radiocarbon dating of the cemetery over the forum of Pollentia (Mallorca, Balearic Islands), Archaeological and Anthropological Sciences, 1-10.

Cerdà, D. (1979). Excavaciones arqueológicas submarinas en la ensenada de la Colònia de San Jordi. Palma de Mallorca, Museu de Mallorca.

Cerdà, D. (1980). La nave romano-republicana de la Colonia de Sant Jordi, Ses Salines, Mallorca. Palma de Mallorca, Monografías del Museo de Mallorca, 6.

Cerdà, D. (1999). El vi en l'ager pollentinus i en el seu entorn. Amb una síntesi de la Palma romana amb el seu port (Portopí). Colecció La Deixa 3, Palma de Mallorca, Monografies de Patrimoni Històric, Consell de Mallorca.

Cerdà, D. (2002). Bocchoris. El món clàssic a la badia de Pollença. Col•lecció Quaderns de Patrimoni Cultural, 8. Palma de Mallorca, Consell de Mallorca Palma.

Colls, D. (1987). L'épave de la Colonia de Sant Jordi 1 (Majorque). Paris, Publications du Centre Pierre Paris, 16. 
Colls, D., Domergue, C., Guerrero, V. (1986). Les lingots de plomb de l'épave Cabrera 5 (île de Cabrera, Baléares), Archaeonautica, 6, 31-80.

Colom Mendoza, E. (2013). La isla de Mallorca como hito marítimo del eje comercial procedente de la Bética en época romana, Arqueología y Territorio, 10, 87-100.

D'Angelo, G., Garguillo, S. (1978). Guida alle Conchiglie Mediterranee, conoscerle, cercarle, collezionarle. Fabri Editori, Milan.

De Falco, G., Molinaroli, E., Baroli, M., Bellaciccob, S. (2003). Grain size and compositional trends of sediments from Posidonia oceanica meadows to beach shore, Sardinia, western Mediterranean. Estuarine, Coastal and Shelf Science, 58(2), 299-309.

Domingo, A., Druguet, G. (2004). El moll del Port Major d'Alcúdia. El primer nucli i les seves instal·lacions fins a la fi del s.XIX, III Jornades d'Estudis Locals. Alcúdia, Ajuntament d'Alcúdia.

Doneddu, M., Trainito, E. (2005). Conchiglie del Mediterraneo. Guida ai molluschi conchigliati. Il castello, Cornaredo.

Farrell, W.E., Clark, J.A. (1976). On post-glacial sea level. Royal Astronomical Society Geophysical Journal, 46, 647-657.

Flaux, C., Claude, C., Marriner, N., Morhange, C. (2013). A 7500 years strontium isotope record from the northwestern Nile delta (Maryut lagoon, Egypt). Quaternary Science Reviews, 78, 22-33.

Fornós, J.J., Ahr, W.M. (2006). Present-day temperate carbonate sedimentation on the Balearic Platform, western Mediterranean: compositional and textural variation along a lowenergy isolated ramp. Geological Society, London, Special Publications, 255(1), 71-84.

Frey, O.H. (1970). Zur archäologischen Unterwasserforschung an den Küsten Mallorcas. Untersuchungen im Hafen von Porto Cristo, Madrider Mitteilungen, 11, 122-8. 
Frost, H. (1973). The offshore island harbour at Sidon and other Phoenician sites in the light of new dating evidence. The International Journal of Nautical Archaeology and Underwater Exploration, 2.1, 75-94.

Giampaola, D., Carsana, V., Boetto, G. (2004). Il mare torna a bagnare Neapolis. Parte II: dalla scoperta del porto al recupero dei relitti. L'archeologo subacqueo, 10, 15-19.

Ginés, A., Fornós, J.J., Ginés, J., Bover, P., Gómez-Pujol, L., Gràcia, F., Merino, A., Vincens, D., (2012). An introduction to the Quaternary of Mallorca, in Ginés, A., Ginés, J., GómezPujol, L., Onac, B.P., Fornós, J.J. (eds.)., Mallorca: A Mediterranean Benchmark for Quaternary Studies. Mon. Soc. Hist. Nat. Balears, 18, 13-53.

Goy, J.L., Zazo, C., Cuerda, J. (1997). Evolución de la áreas margino-litorales de la costa de Mallorca (I. Baleares) durante el Último y Presente Interglaciar nivel del mar Holoceno y clima. Boletín Geológico Y Minero, 108, 127-135.

Gracia, F., Clamor, B., Gracia, P., Merino, A., Vega, P., Mulet, G. (2001). Notícia preliminar del jaciment arqueològic de la font de Ses Aiguades (Alcúdia, Mallorca), Endins, 24, 59-73.

Guelorget, O., Perthuisot, J.P. (1983). Le domaine paralique. Expressions géologiques, biologiques et économiques du confinement. Travaux du laboratoire de Géologie, Ecole Normale Supérieure Paris, 16, 1-136.

Guerrero Ayuso, V.M. (1984). Asentamiento púnico de Na Guardis. Excavaciones Arqueológicas en España, vol. 133. Madrid : Ministerio de Cultura.

Guerrero Ayuso, V.M. (1985). El fondeadero Norte de na Guardis: su contribución al conocimiento de la colonización púnica en Mallorca, in VI Congreso Internacional de Arqueología Submarina. Cartagena 1982, 225-264.

Guerrero Ayuso, V.M. (1987). La Colònia de Sant Jordi (Mallorca): estudis d'arqueologia i epigrafia. Palma de Mallorca, Publicacions del Centre d'Estudis "Gabriel Alomar". 
Guerrero Ayuso, V.M. (1993). Navíos y Navegantes en las rutas de Baleares durante la Prehistoria. Palma de Mallorca, El Tall.

Guerrero Ayuso, V.M. (1997). Colonización púnica de Mallorca. Palma de Mallorca, El Tall. Guerrero Ayuso, V. M. (2004). Las islas Baleares en las rutas de navegación del Mediterráneo central y occidental. In Peña, V., Mederos, A. and Wagner, C. G., La Navegación Fenicia: Tecnología Naval y Derroteros. Centro de Estudios Fenicios y Púnicos, Universidad Complutense, Madrid, 85-134.

Guerrero Ayuso, V.M. (2006). Nautas baleáricos durante la Prehistoria (Parte I). Condiciones meteomarinas y de navegación de cabotaje, Pyrenae, 37(1), 87-129.

Guerrero Ayuso, V. M., Colls, D. (1982). Exploraciones arqueológicas submarinas en la bocana del puerto de Cabrera (Baleares), Bolletí de la Societat Arqueológica Lul•liana, 39, 322.

Hammer, O., Harper, D.A.T., Ryan, P.D. (2001). PAST: paleontological Statistics software package for education and data analysis, Palaeontol. Electron., 4, 1-9

Heiri, O., Lotter, A.F., Lemcke, G. (2001). Loss on ignition as a method for estimating organic and carbonate content in sediments: reproducibility and comparability of results. J. Paleolimnol., 25, 101-110

Jeudy de Grissac, A., Boudouresque, C.F. (1985). Rôles des herbiers de phanérogames marines dans les mouvements des sédiments côtiers: les herbiers à Posidonia oceanica. Les aménagements côtiers et la gestion du littoral, Coll. pluridisciplinaire franco-japonais océanographie, 143-151.

Kaniewski, D., Paulissen, E., Van Campo, E., Al-Maqdissi, M., Bretschneider, J., Van Lerberghe, K. (2008). Middle East coastal ecosystem response to middle-to-late Holocene abrupt climate Changes. P. Natl. Acad. Sci. U. S. A., 105, 13941-13946 
Kaniewski, D., Giaime, M., Marriner, N., Morhange, C., Otto, T., Porotov, A.-V., Van Campo, E. (2015). First evidence of agro-pastoral farming and anthropogenic impact in the Taman Peninsula, Russia. Quaternary Science Reviews, 114, 43-51.

Kjerfve, B. (1986). Comparative oceanography of coastal lagoons. Estuarine Variability. (WolfeD.A., 4.). Academic Press, New York, 63-81.

Lachenal, A.M. (1989). Ecologie des ostracodes du domaine méditerranéen : application au golfe de Gabès (Tunisie orientale) : les variations du niveau marin depuis 30000 ans. Docum. Lab. Géol. Lyon, 108.

Manera, E. (1983). Lucernas romanas procedentes de Porto Cristo (Manacor, Mallorca)I In Arribas, A. (Ed.), Pollentia. Estudio de los materiales I. Sa Portella. Excavaciones 1957-63. Palma, 367-400.

Marriner, N., (2009). Geoarchaeology of Lebanon's ancient harbours. Archaeopress, British Archaeological Reports, S1953, Oxford.

Marriner, N., Morhange, C. (2006a). The 'Ancient Harbour Parasequence’: anthropogenic forcing of the stratigraphic highstand record. Sedimentary Geology, 186, 13-17.

Marriner, N., Morhange, C. (2006b). Geoarchaeological evidence for dredging in Tyre's ancient harbour, Levant. Quaternary Research, 65, 64-171.

Marriner, N., Morhange, C. (2007). Geoscience of ancient Mediterranean harbours. Earth Sci. Rev., 80, 137-194.

Marriner, N., Morhange, C., Doumet-Serhalb, C. (2006). Geoarchaeology of Sidon's ancient harbours, Phoenicia. Journal of Archaeological Science, 33, 1514-1535.

Marriner, N., Morhange, C., Kaniewski, D., Carayon, N. (2014). Ancient harbour infrastructure in the Levant: tracking the birth and rise of new forms of anthropogenic pressure. Scientific Reports, 4, 5554. 
Mascaró Pasarius, J. (1971). El tráfico marítimo en Mallorca en la antigüedad clásica, in III Congreso Internacional de Arqueología Submarina (Barcelona, 1961). Bordighera, 69-86.

Morhange, C., Marriner, N. (2010a). Palaeo-hazards in the coastal Mediterranean: a geoarchaeological approach, in Martini, I. P. et Chesworth, W. (eds.), Landscapes and Societies. Springer, Dordrecht, The Netherlands, 223-234.

Morhange, C., Marriner, N. (2010b). Mind the (stratigraphic) gap: Roman dredging in ancient Mediterranean harbours. Bollettino di Archeologia online, 23-32.

Morhange, C., Goiran, J.P., Bourcier, M., Carbonel, P., Le Campion, J., Rouchy, J.M., Yon, M., (2000). Recent Holocene Paleo-environmental evolution and coastline changes of Kition, Larnaca, Cyprus, Mediterranean Sea. Marine Geology, 170, 205-230.

Morhange, C., Blanc, F., Bourcier, M., Carbonel, P., Prone, A., Schmitt-Mercury, S., Vivent, D. (2003). Bio-sedimentology of the late Holocene deposits of the ancient harbor of Marseille (Southern France, Mediterranean Sea). The Holocene, 13, 593-604.

Morhange, C., Pirazzoli, P.A., Evelpidou, N., Marriner, N. (2012). Late Holocene tectonic uplift and the silting up of Lechaion, the western harbor of ancient Corinth, Greece. Geoarchaeology, 27(3), 278-283.

Morhange, C., Marriner, N., Blot, M.L., Bony, G., Carayon, N., Carmona, P., Flaux, C., Giaime, M., Goiran, J.P., Kouka, M., Lena, A., Oueslati, A., Pasquinucci, M., Porotov, A.V. (2015). Dynamiques géomorphologiques et typologie géoarchéologique des ports antiques en contextes lagunaires. Quaternaire, 26(2), 117-139.

Morhange, C., Marriner, N., Bony, G., Flaux, C., Giaime, M., Kouka, M. (2016). Geoarchaeology of ancient harbours in lagoonal contexts: an introduction. In T. Franconi (ed.), Fluvial landscapes in the Roman world, Journal of Roman Archaeology, supplementary series $104,97-110$.

Mourtzas, N.D., Kissas, C., Kolaiti, E. (2014). Archaeological and geomorphological 
indicators of the historical sea level changes and the related palaeogeographical reconstruction of the ancient foreharbour of Lechaion, East Corinth Gulf (Greece). Quaternary International, 332, 151-171.

Munar, S., Sastre, M.À. (2010). El portus de Pollentia. Resultats preliminars de la intervenció arqueològica al solar del carrer Corall, cantonada amb carrer Maristany (Port d'Alcúdia), VI Jornades d'Estudis Locals d'Alcúdia, Alcúdia, 31-46.

Muntaner, A. (1980). Carácteres físicos, Geología. In Estudio ecologico de la Albufera de Mallorca (Alcúdia, Muro y Sa Pobla), Barceló, B., and Mayol, J. (eds.) (UIB), 27-46.

Nieto, X., Santos, M., Tarongí, F. (2002). Un barco griego del siglo VI a.C. en Cala Sant Vicenç (Pollença, Mallorca). In Peña, V., Mederos A., Wagner, C. G, La Navegación Fenicia; Tecnología Naval y Derroteros. Encuentro entre marinos, arqueólogos e historiadores. Madrid : Centro de Estudios Fenicios y Púnicos, 197-226.

Nieto, X., Santos, M. (2008). El vaixell grec arcaic de Cala Sant Vicenç. Monografies del CASC, 7, Girona.

Orfila, M., Arribas, A., Cau, M.A. (1999). La ciudad roman de Pollentia; el foro, Archivo Español de Arqueología, 62, 99-118.

Orfila, M., Chávez, M.E., Cau, M.A. (2006). Pollentia and the Roman cities of the Balearic Islands, in Abad, L., Keay, S., Ramallo, S., (coords.), Early Roman towns in Hispania Tarraconensis, Supplement of the Journal of Roman Archaeology 62, 133-144.

Orfila, M., Riera, M. (2002). Alguns vestigis d'època islàmica al fòrum de Pollentia. In: Homenatge a Guillem Rosselló Bordoy. Govern de les Illes Balears. Conselleria d’Educació i Cultura, Palma, 705-724.

Peltier, W.R. (2004). Global glacial isostasy and the surface of the ice-age earth: the ice-5G (VM2) model and grace. Annu. Rev. Earth Planet. Sci., 32, 111-149.

Pigati, J.S., Rech, J.A., Nekola, J.C. (2010). Radiocarbon dating of small terrestrial gastropod 
shells in North America. Quaternary Geochronology, 5, 519-532.

Pons Valens, J.M., Riera Frau, Ma.M., Riera Rullan, M. (2001). Història i Arqueologia de Cabrera. Colecció Eines, 6. Palma de Mallorca, Ajuntament de Palma.

Poppe, G., Goto, Y. (1991). European Seashells, vol. I, Verlag Christa Hemmen, Weisbaden.

Poppe, G., Goto, Y. (1993). European Seashells, vol. II, ConchBooks, Hackenheim.

Puig Palerm, A. (2011). El derelicte de les llumetes de Porto Cristo. Causes i data de la troballa. In Ferrer Febrer, A., Salas Burguera, M. (Eds.). Manacor. Fets i Protagonistes. VI Jornades d'Estudis Locals de Manacor (Manacor, 2010), 37-42.

Puig Palerm, A. (2015): Portocristo, port romà. Una hipòtesi per analitzar. In Ferrer Febrer, A., Salas Burguera, M. (Eds.), Religiositat i moviments socials a Manacor. VIII Jornades d'Estudis Locals de Manacor (Manacor, 2014), 175-190.

Reimer, P.J., Bard, E., Bayliss, A., Beck, J.W., Blackwell, P.G., Ramsey, C.B., Buck, C.E., Cheng, H., Edwards, R.L., Friedrich, M., Grootes, P.M., Guilderson, T.P., Haflidison, H., Hajdas, I., Hatté, C., Heaton, T., Hoffmann, D.L., Hogg, A., Hughen, K.A., Kaiser, K., Kromer, B., Manning, S.W., Niu, M., Reimer, R., Richards, D.A., Scott, E.M., Southon, J.R., Staff, R., Turney, C., Van der Plicht, J. (2013). IntCal13 and Marine13 Radiocarbon Age calibration Curves 0-50,000 years cal BP. Radiocarbon, 55, 1869-1887.

Riera, M., Martin, A. (2009). El port de Portocolom (Illa de Mallorca) durant l'antiguitat tardana, Mayurqa, 33(1), 175-192.

Ruiz de Arbulo, J. (1990). Rutas marítimas y colonizaciones en la Península Ibérica. Una aproximación náutica a algunos problemas, Italica. Cuadernos de Trabajos de la Escuela Española de Historia y Arqueología de Roma, 18, 79-115.

Sàbat, F., Gelabert, B., Rodríguez-Perea, A., Giménez, J. (2011). Geological structure and evolution of Majorca: Implications for the origin of the Western Mediterranean. Tectonophysics, 510 (1-2), 217-238. 
Salel, T., Bruneton, H., Lefèvre, D. (2016). Ostracods and environmental variability in lagoons and deltas along the north-western Mediterranean coast (Gulf of Lions, France and Ebro delta, Spain). Revue de Micropaléontologie.

Salomon, F., Keay, S., Carayon, N., Goiran, JP. (2016) The Development and Characteristics of Ancient Harbours-Applying the PADM Chart to the Case Studies of Ostia and Portus. PLoS ONE 11(9): e0162587. doi:10.1371/journal.pone.0162587

Santisteban, J.I., Mediavilla, R., Lopez-Pamo, E., Dabrio, C.J., Zapata, M.B.R., Garcia, M.J.G., Castano, S., Martínez-Alfaro, P.E. (2004). Loss on inition: a qualitative or quantitative method for organic matter and carbonate mineral content in sediments? J. Paleolimnol., 32, 287-299.

Servera, J., Gelabert, B., Rodríguez-Perea, A. (2009). Development and setting of the Alcúdia Bay beach-dune system (Mallorca, Spain). Geomorphology, 110(3-4), 172-181.

Silva, P.G., Gonzalez-Hernandez, F.M., Goy, J.L., Zazo, C., Carrasco, P. (2001). Paleo and historical seismicity in Mallorca (Baleares, Spain): a preliminary approach. Acta Geologica hispanica, 36(3-4), 245-266.

Spada, G., Stocchi, P. (2007). SELEN: A Fortran 90 program for solving the "sea-level equation”. Computers \& Geosciences, 33, 538-562.

Stanley, J.D., Warne, A.G. (1994). Worldwide Initiation of Holocene Marine Deltas by Deceleration of Sea-Level rise. Science, 265, 228-231.

Stefaniuk, L., Morhange, C. (2010). Evoluzione dei paesaggi littorali nella depression sudovest di Cuma da 4000 anni, il problema del porto antico. Atti del 40 convegno di sudi sulla Magna Grecia, Taranto (2008), Napoli, 305-322.

Stefaniuk, L., Brun, J.P., Munzi, P., Morhange, C. (2003). L'evoluzione dell'ambiente nei Campi Flegrei e le sue implica- zioni storiche : il caso di Cuma e le ricerche del Centre Jean Bérard nella laguna di Licola. In A. Stazio A., Ceccoli, C., (eds.), Ambiente e paesaggio nella 
Magna Grecia : atti del quarantaduesimo Convegno di studi sulla Magna Grecia, Taranto, 5-8 ottobre 2002. Istituto per la Storia e l'Archeologia della Magna Grecia, Taranto, 397-435.

Stiros, S., Pirazzoli, P., Rothaus, R., Papageorgiou, S., Laborel, J., Arnold, M. (1996). On the date of construction of Lechaion, western harbor of ancient Corinth, Greece. Geoarchaeology, 11(3), 251-263.

Stewart, I., Morhange, C. (2009). Coastal geomorphology and sea-level change. In Woodward, J., (Ed.), The physical geography of the Mediterranean. Oxford University press, 385-413.

Stuiver, M., Reimer, P.J. (1993). Extended 14C database and revised CALIB radiocarbon calibration program. Radiocarbon, 35, 215-230.

Vacchi, M., Marriner, N., Morhange, C., Spada, G., Fontana, A., Rovere, A. (2016). Multiproxy assessment of Holocene relative sea-level changes in the western Mediterranean: Sea-level variability and improvements in the definition of the isostatic signal. Earth-Science Rewiews, 155, 172-197.

VVAA (2007). Arqueologia i Història a Portocolom. Govern de les Illes Balears Palma. 
Fig.1
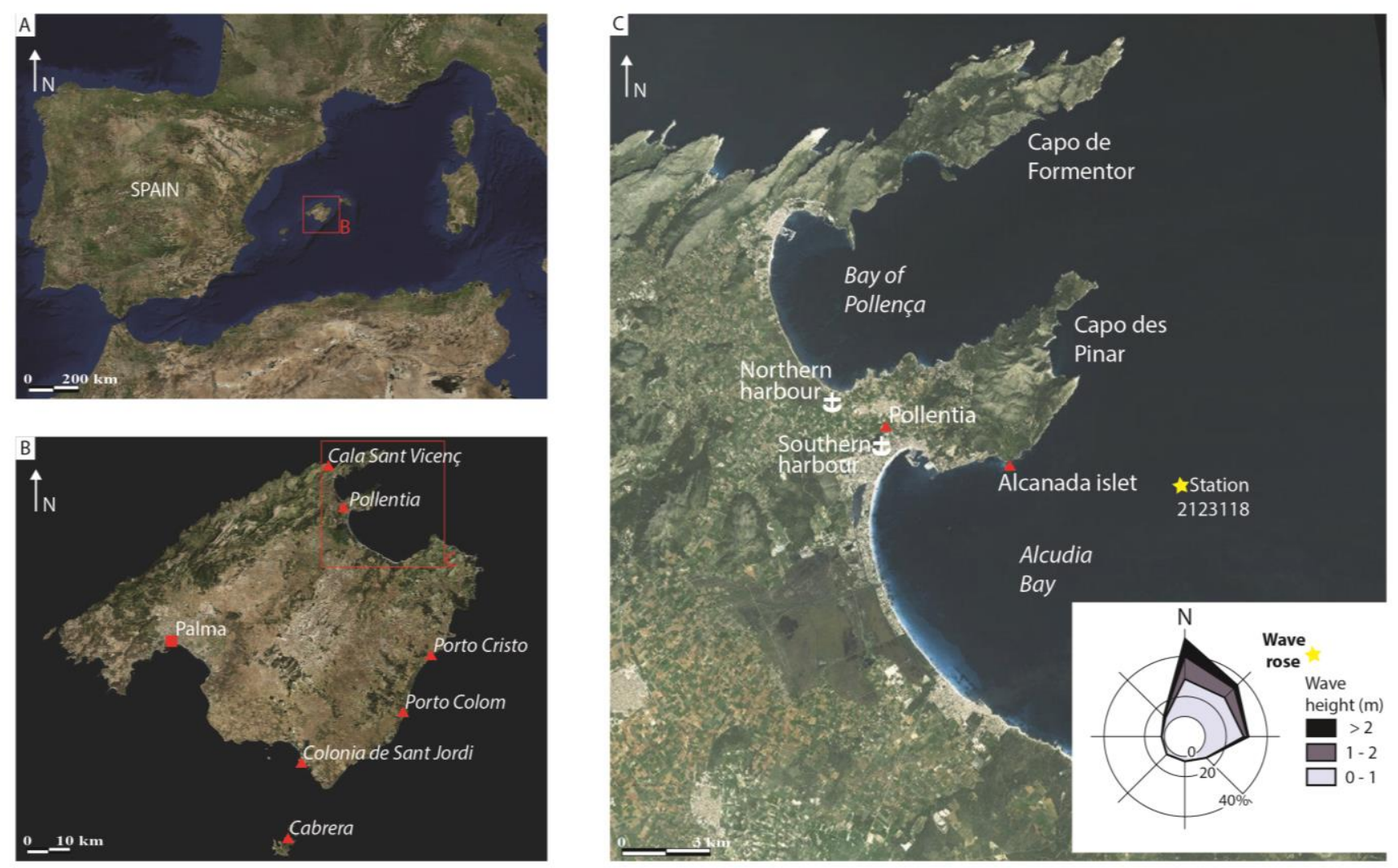
Fig. 2

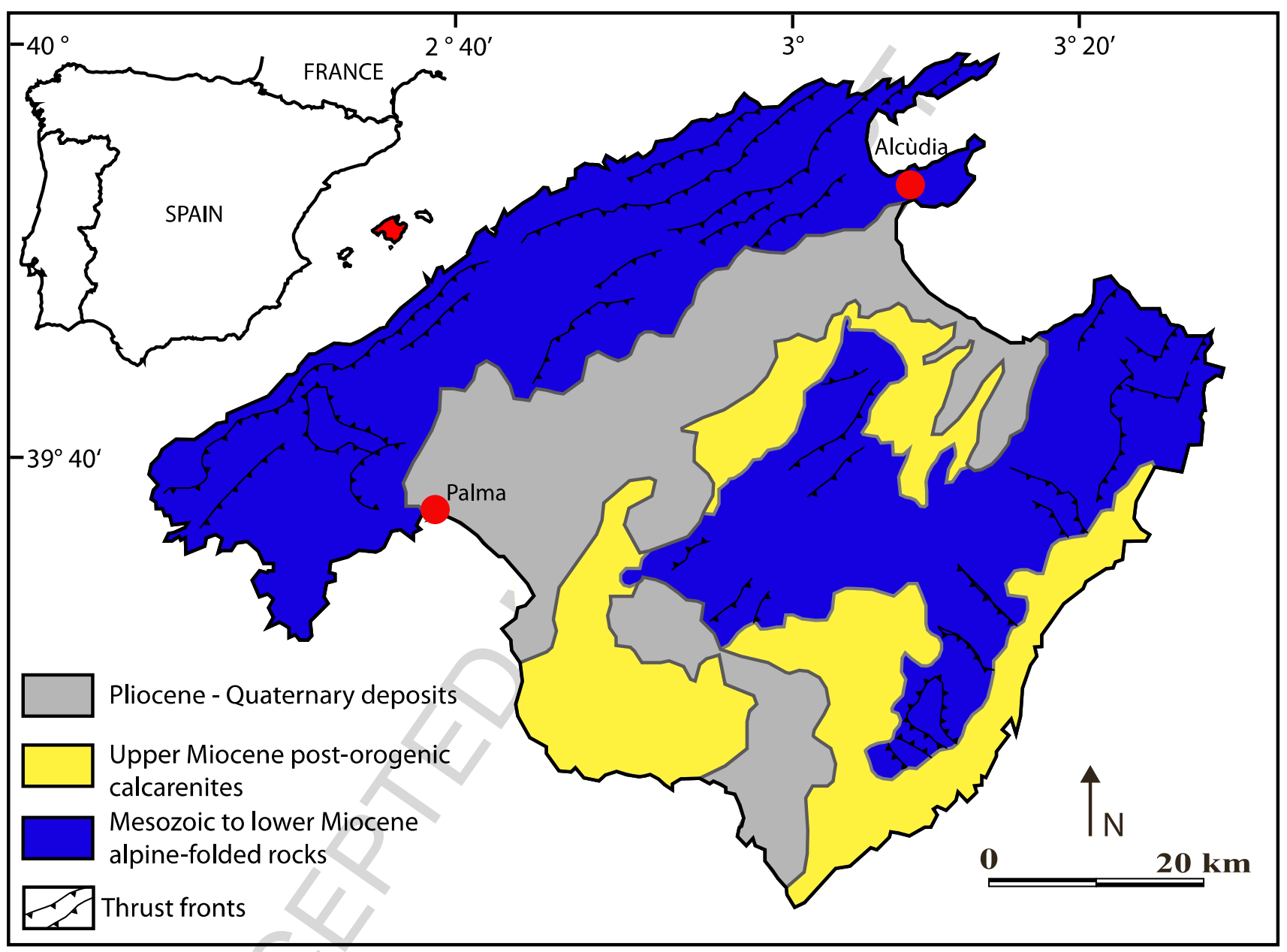


Fig.3
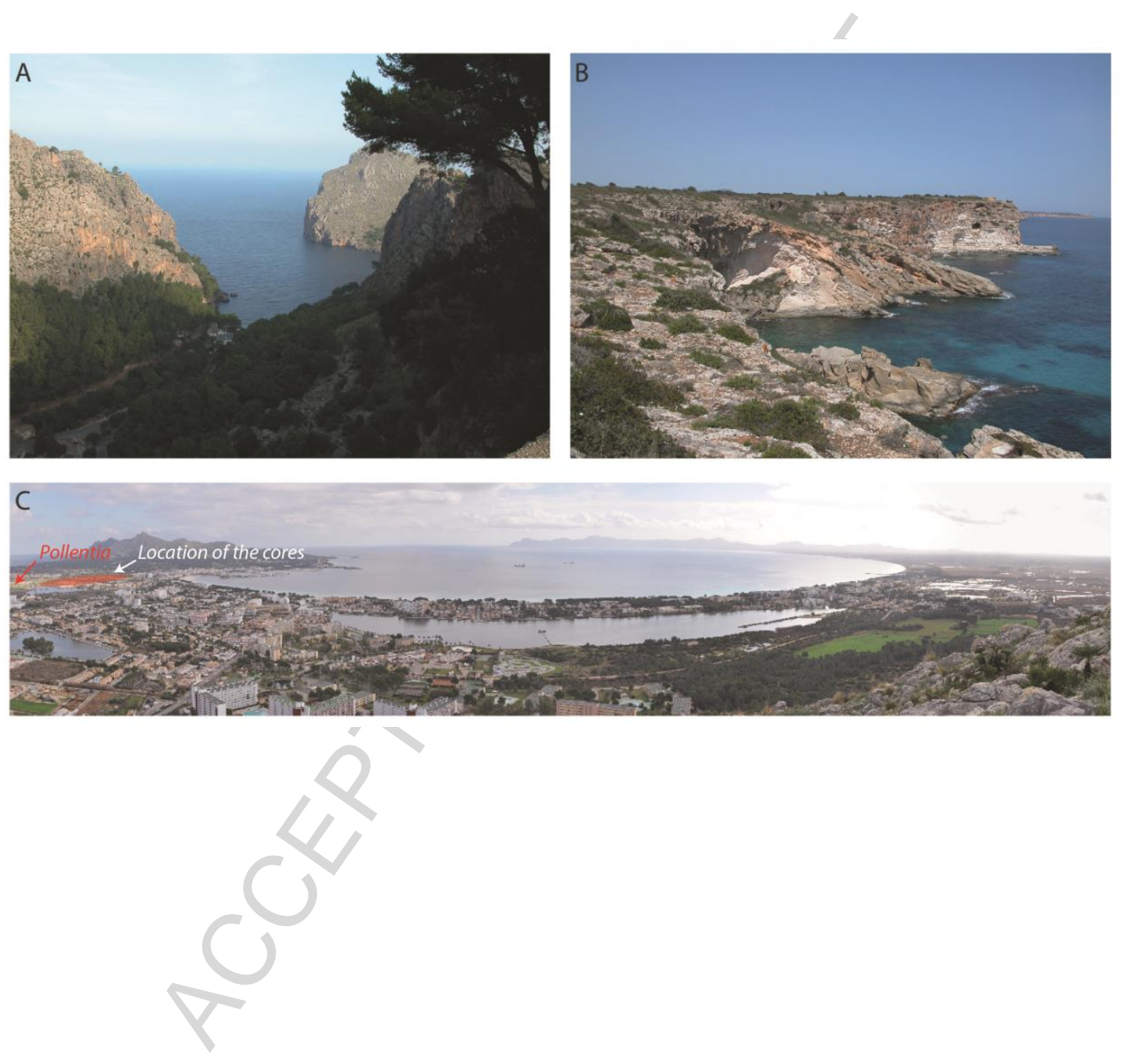
Fig.4

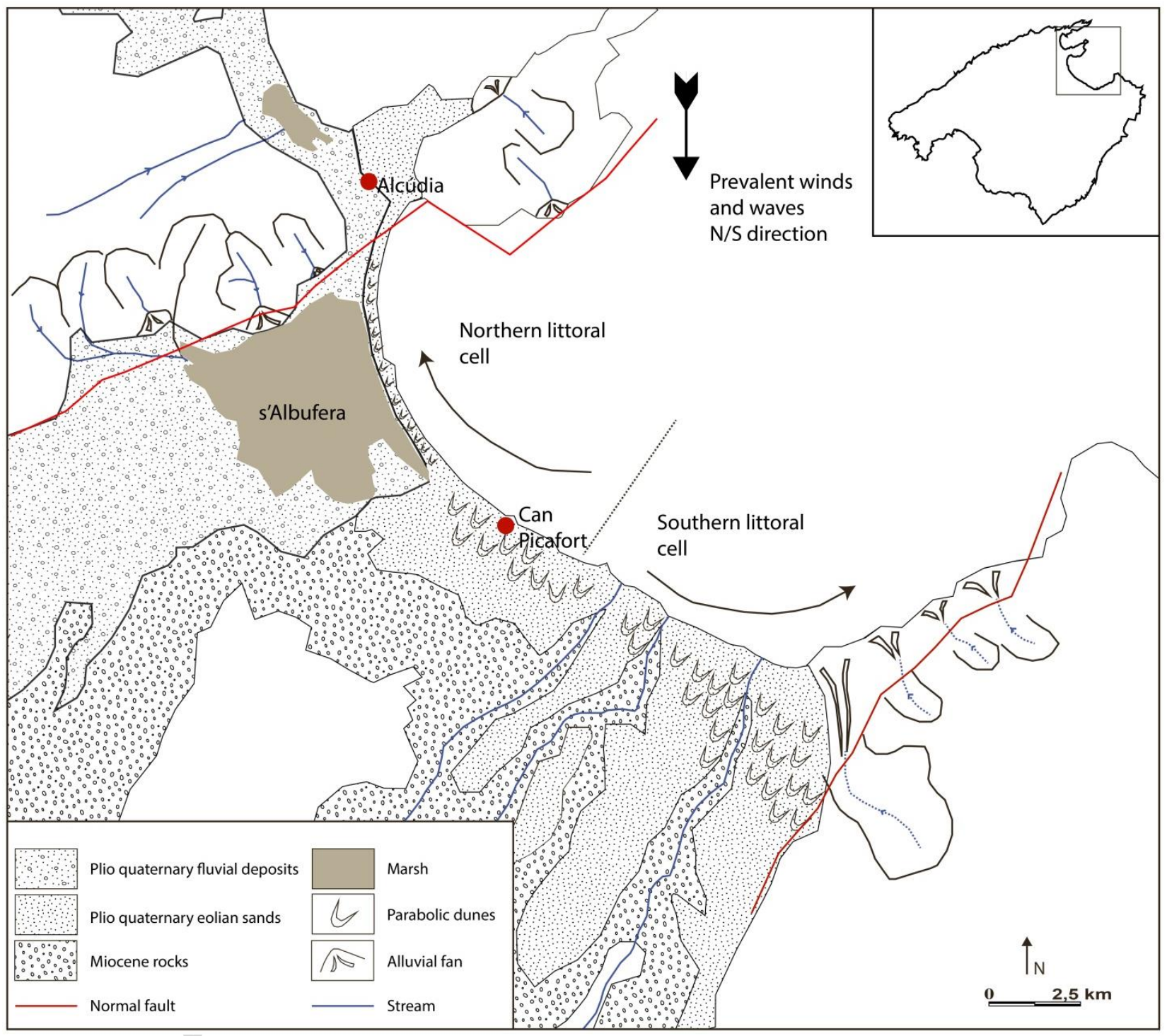


Fig.5

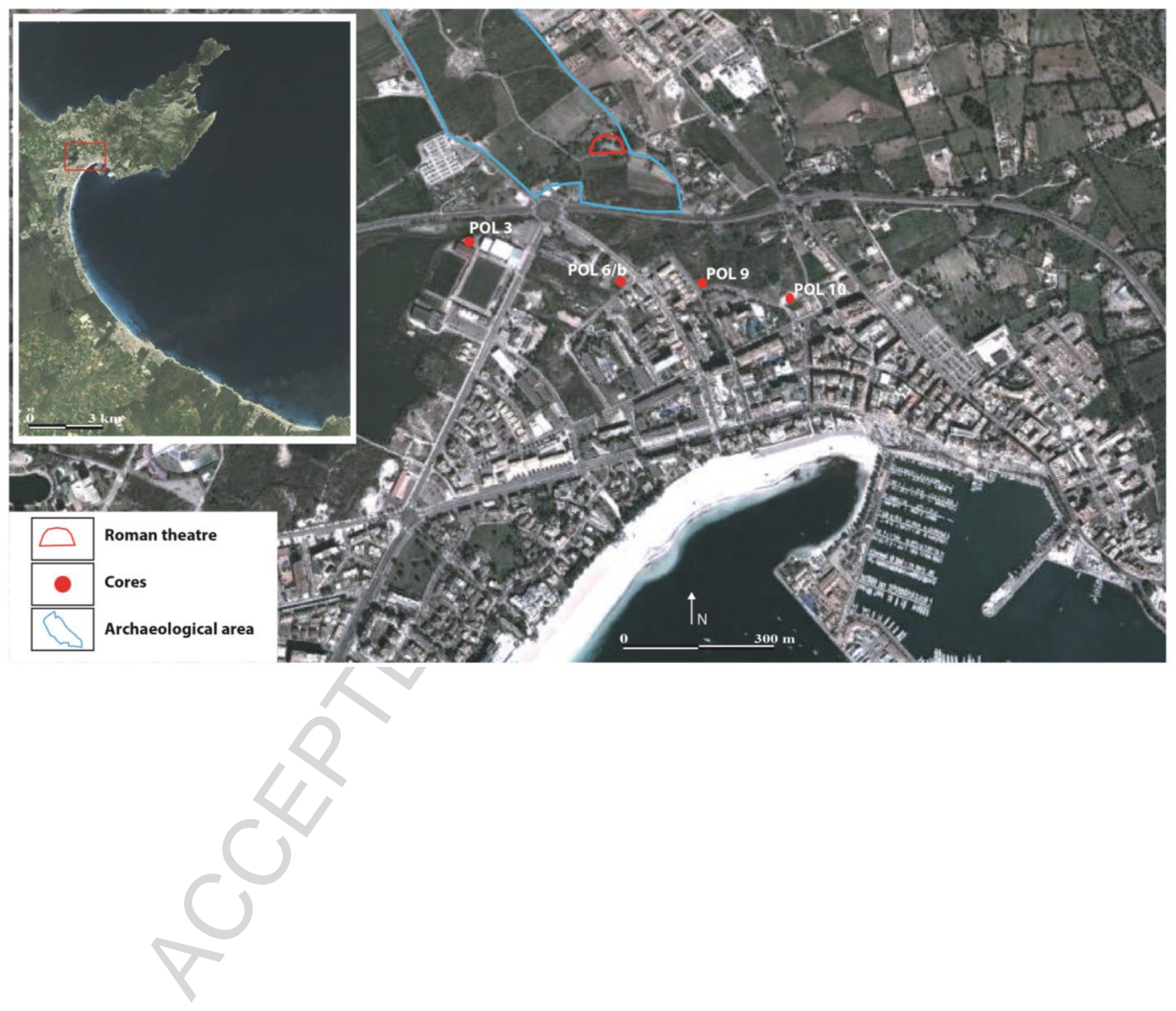


Fig.6

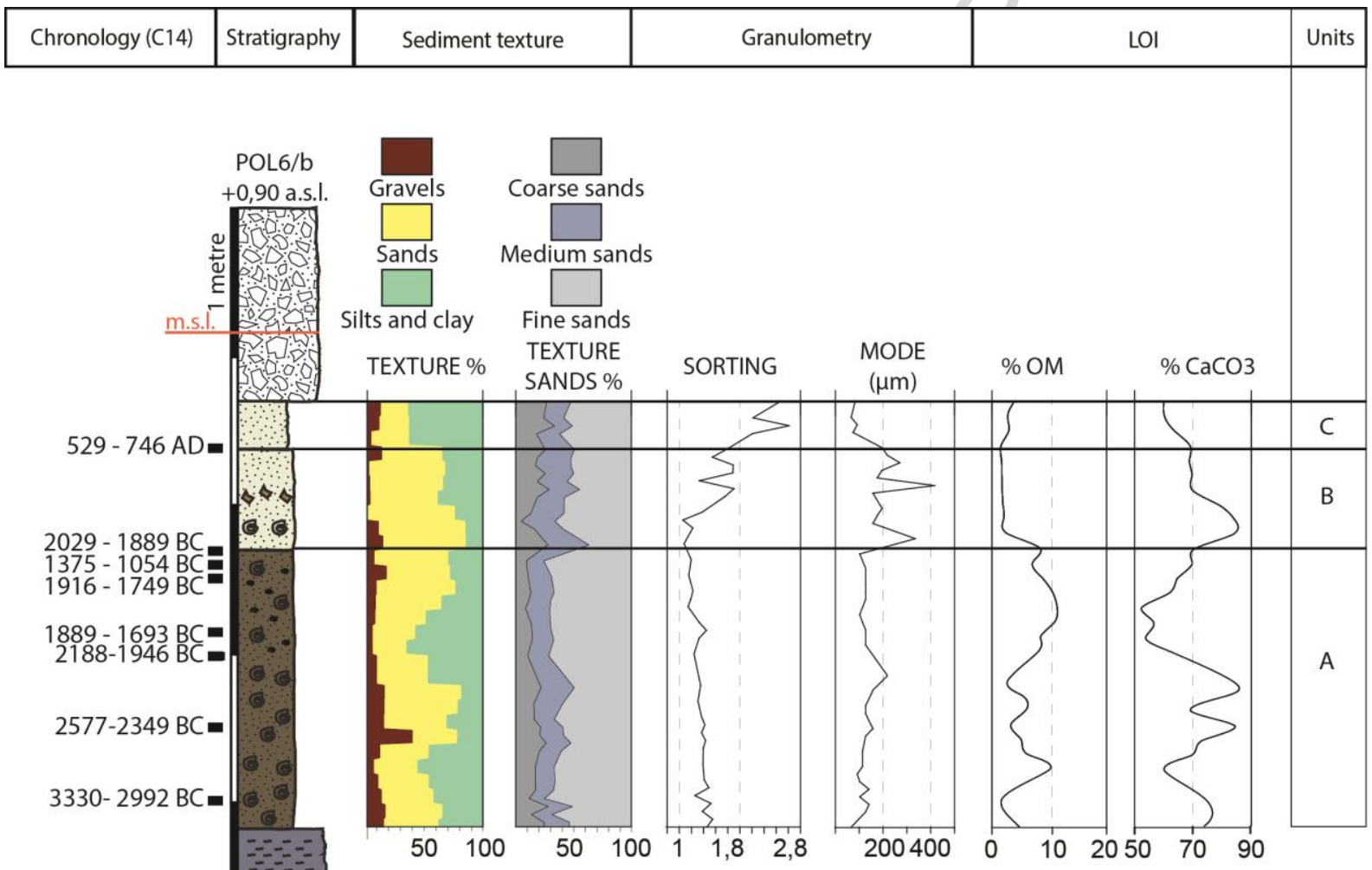


Fig.7
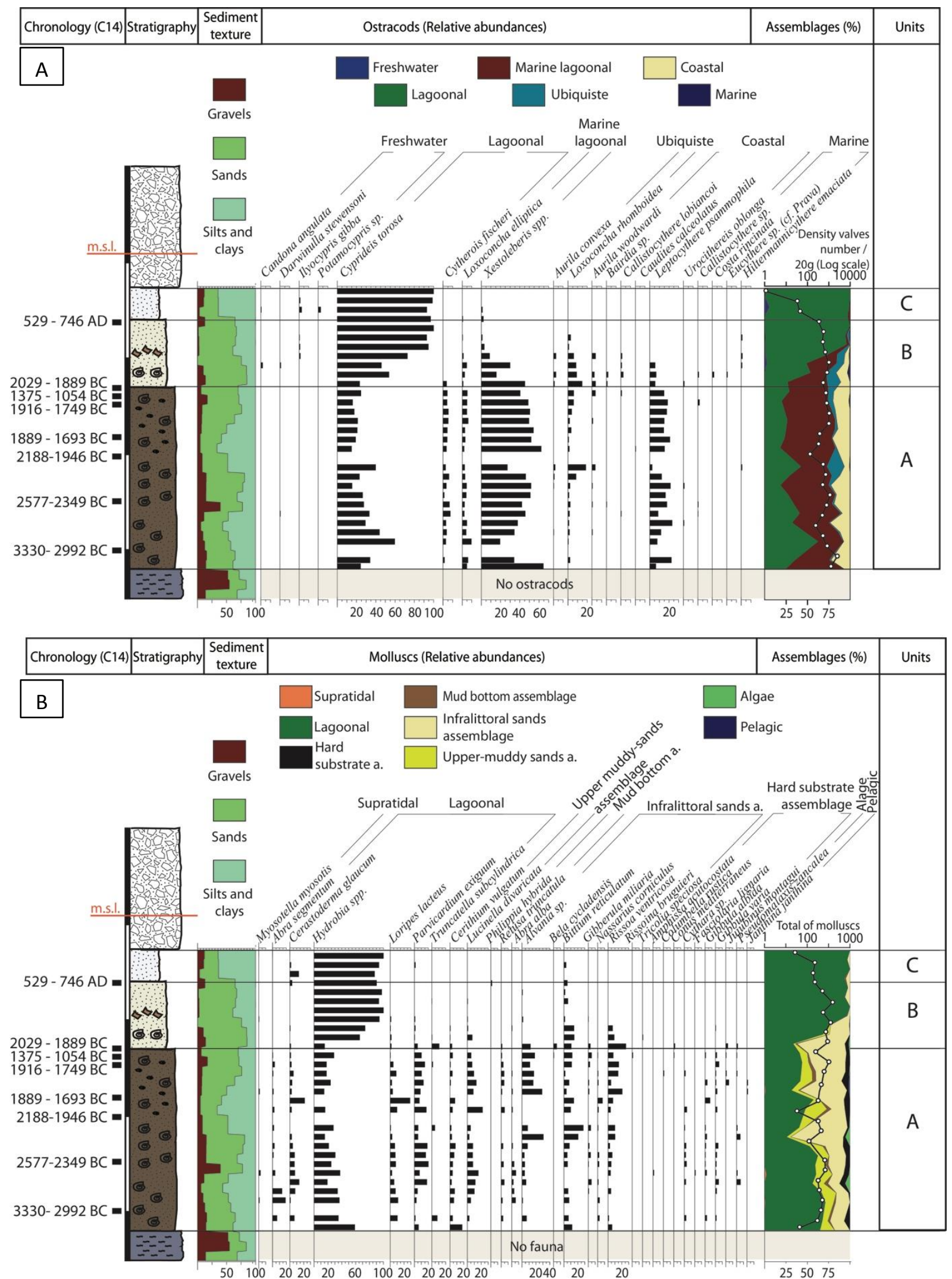
Fig.8

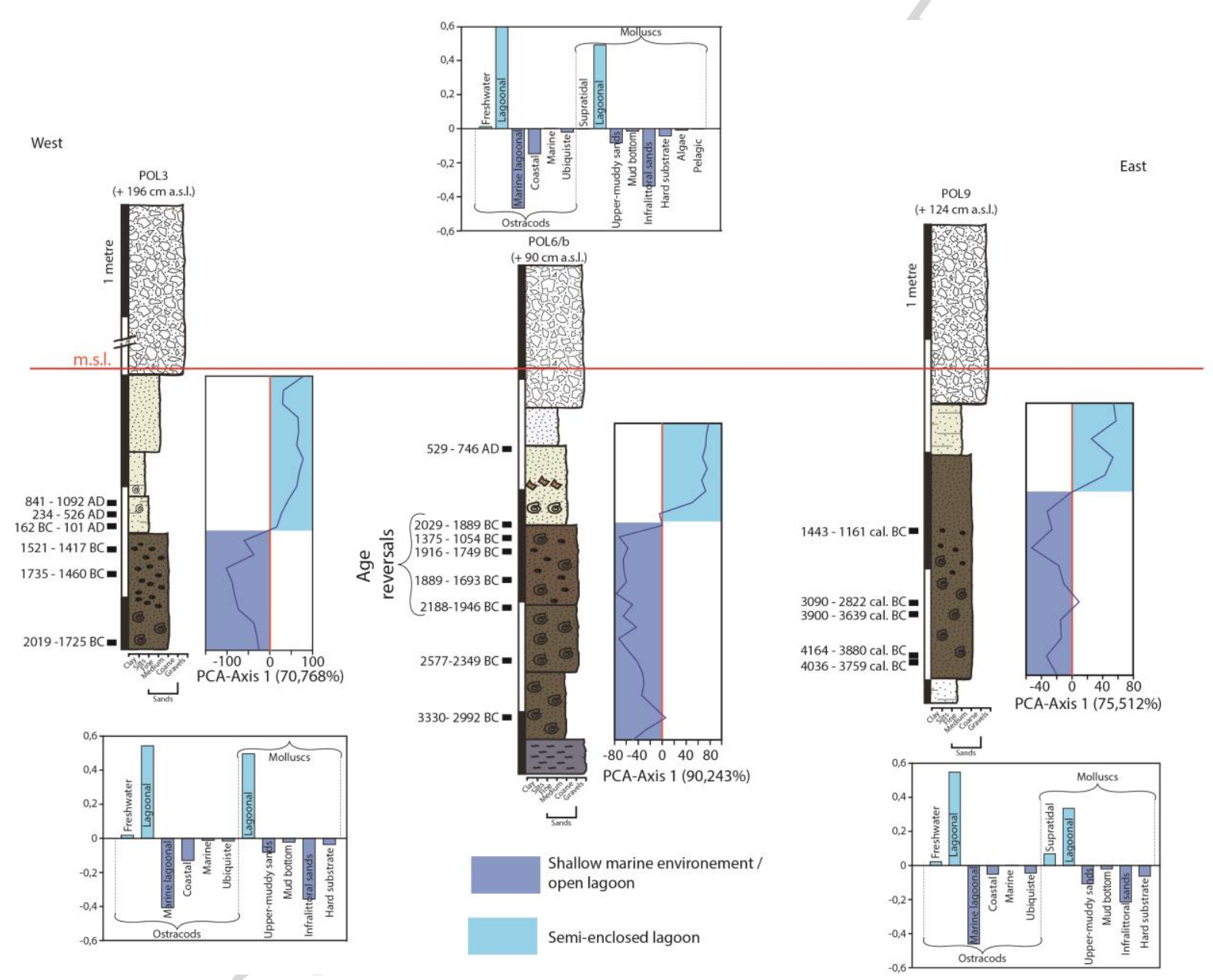


Fig.9

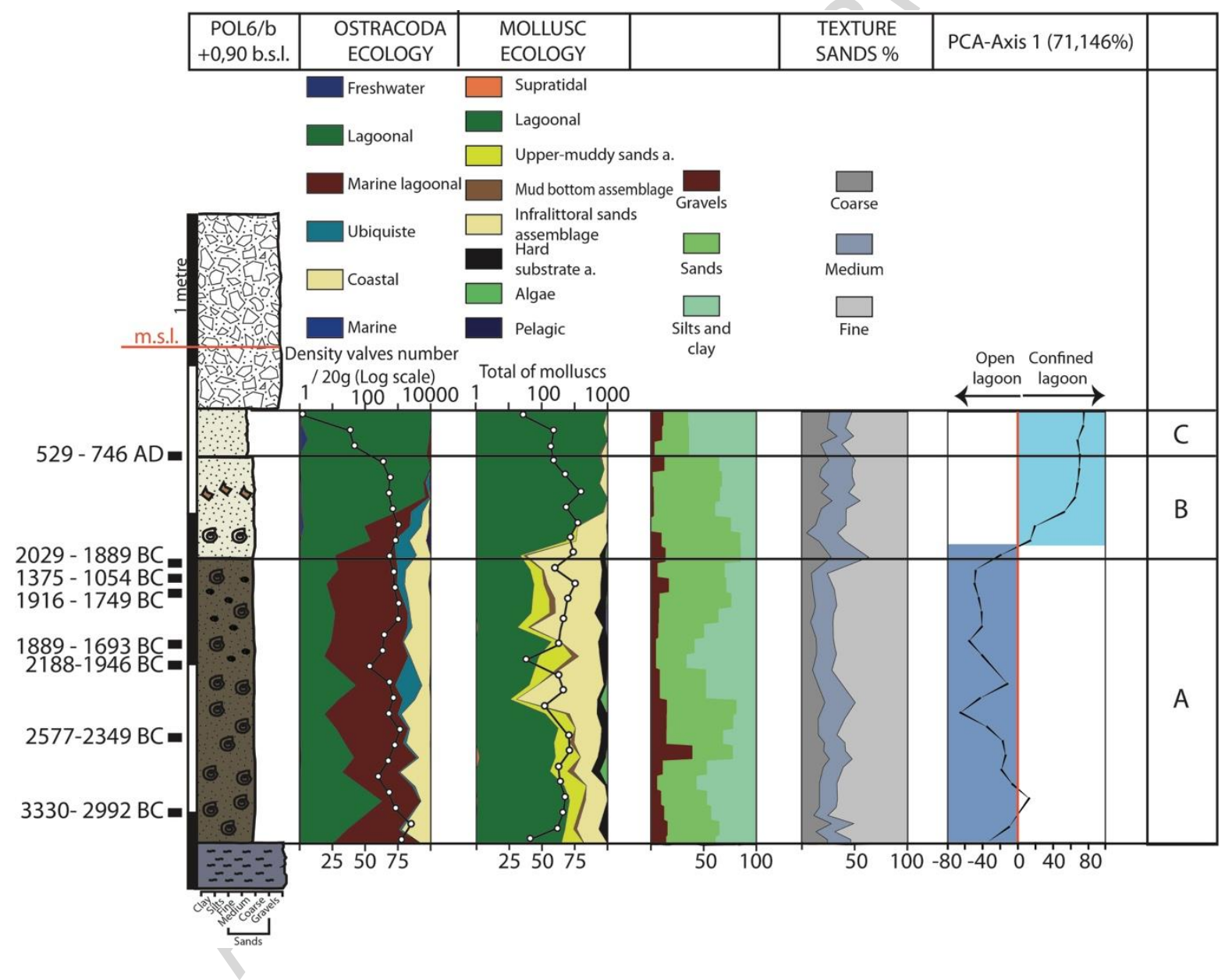


Fig.10

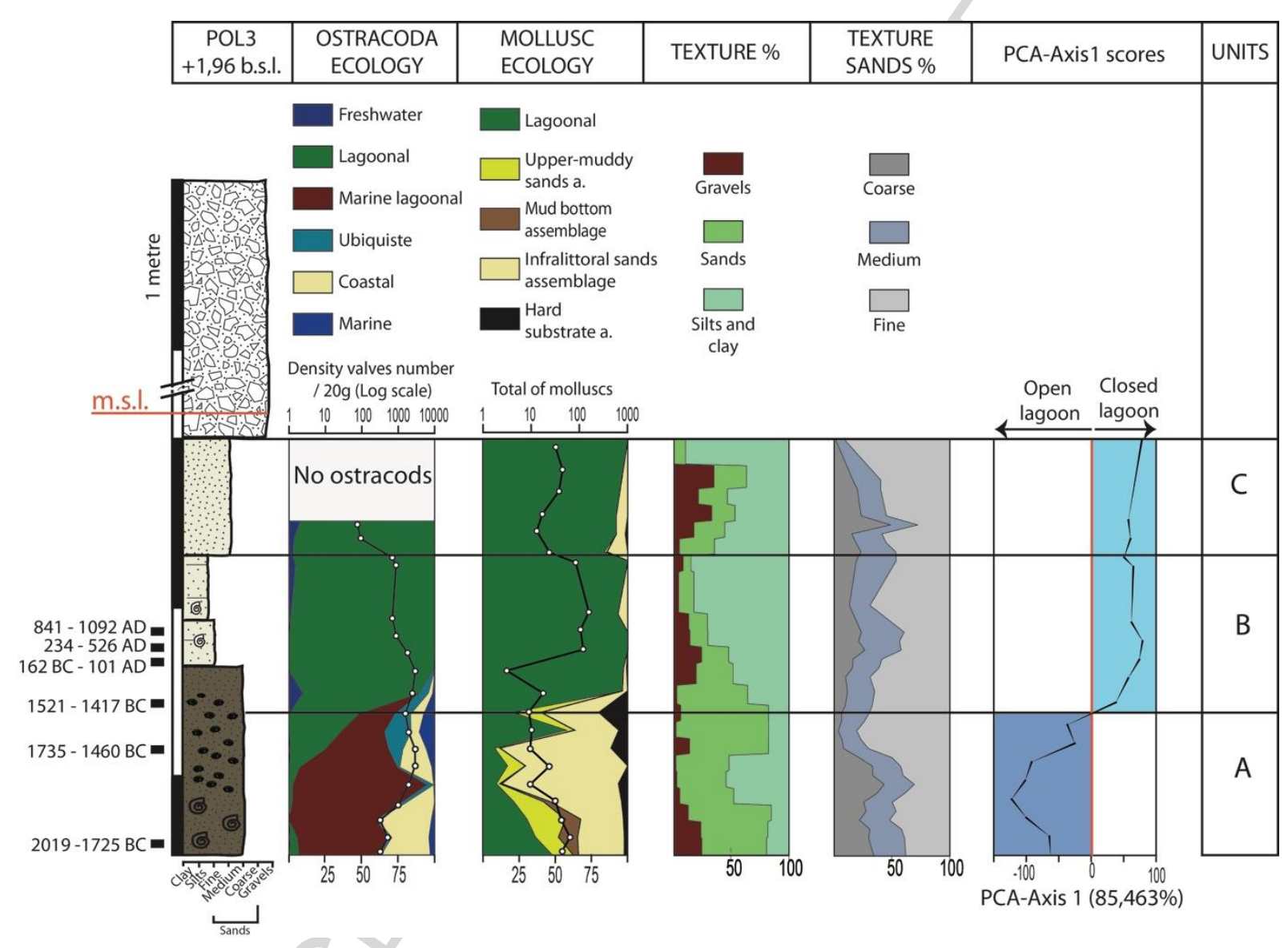


Fig.11

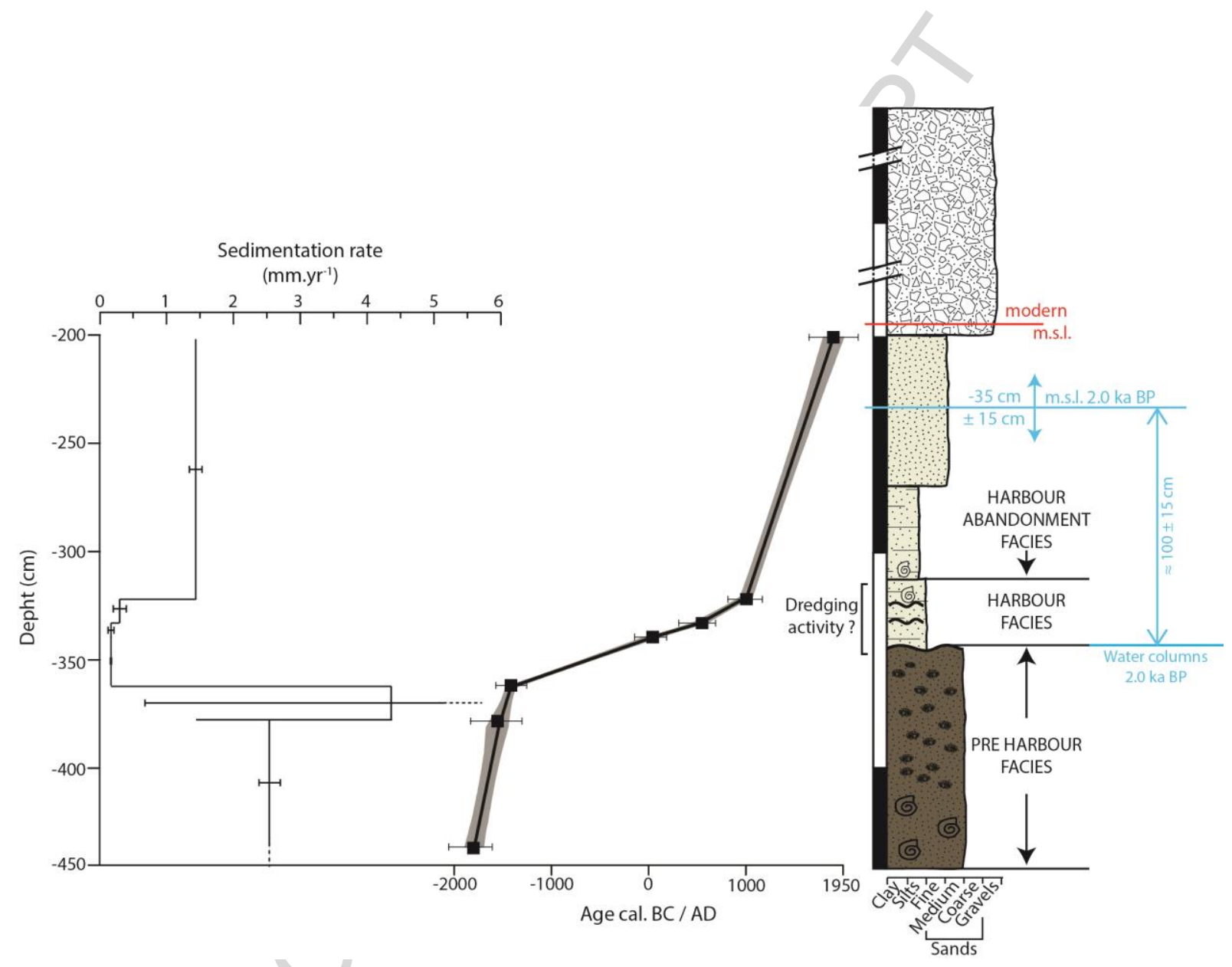


Fig.12

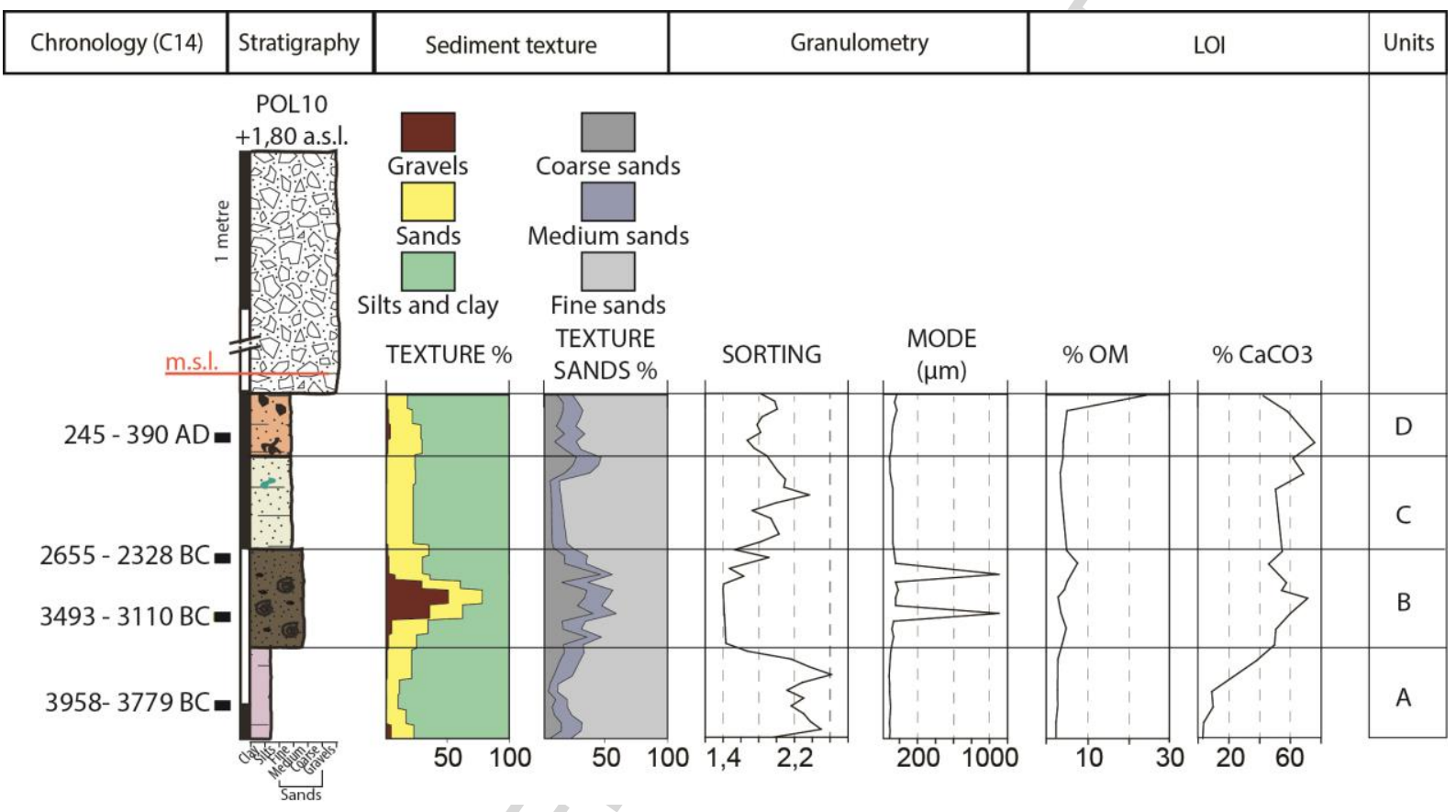


Fig.13
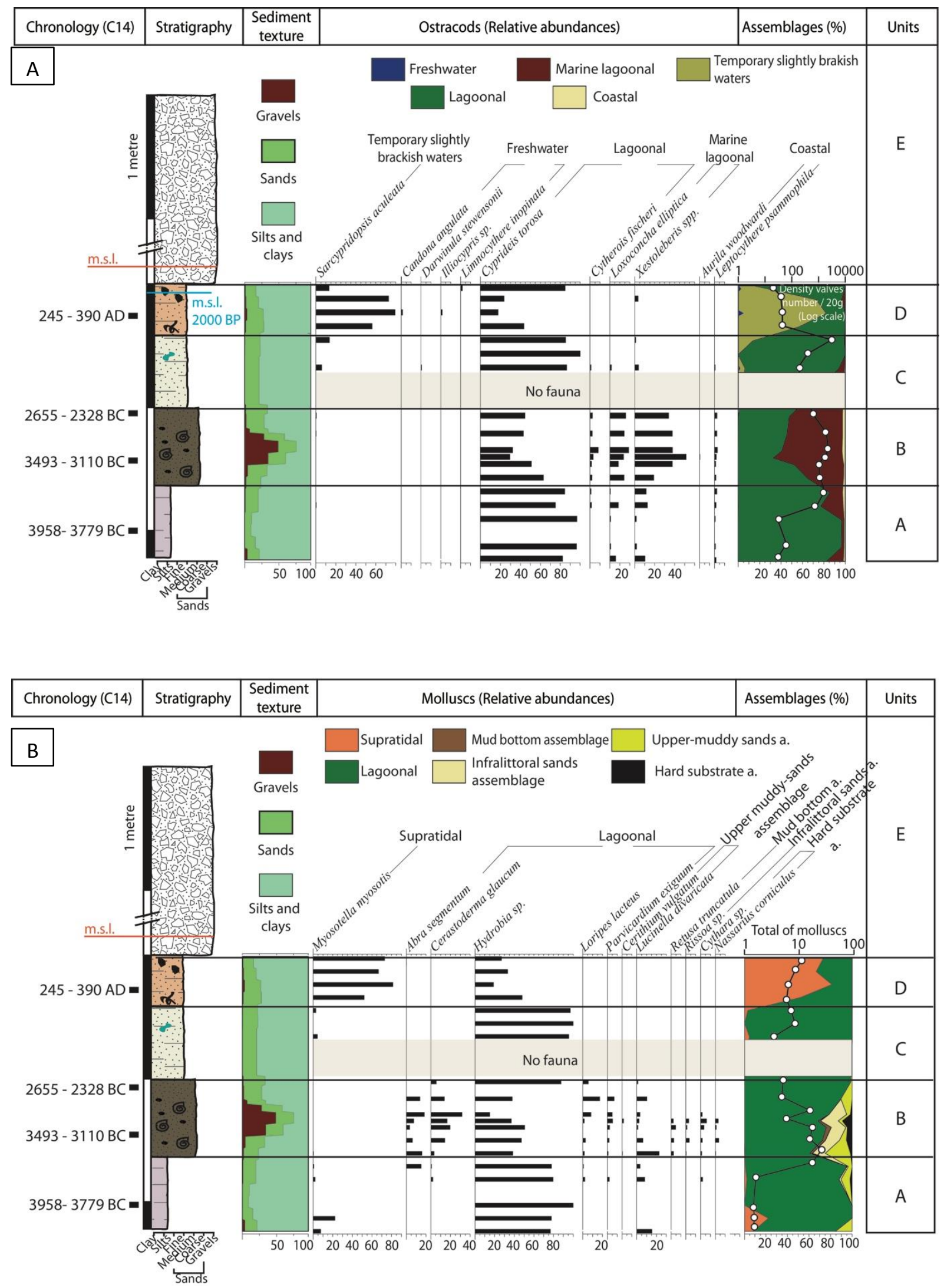
Fig.14

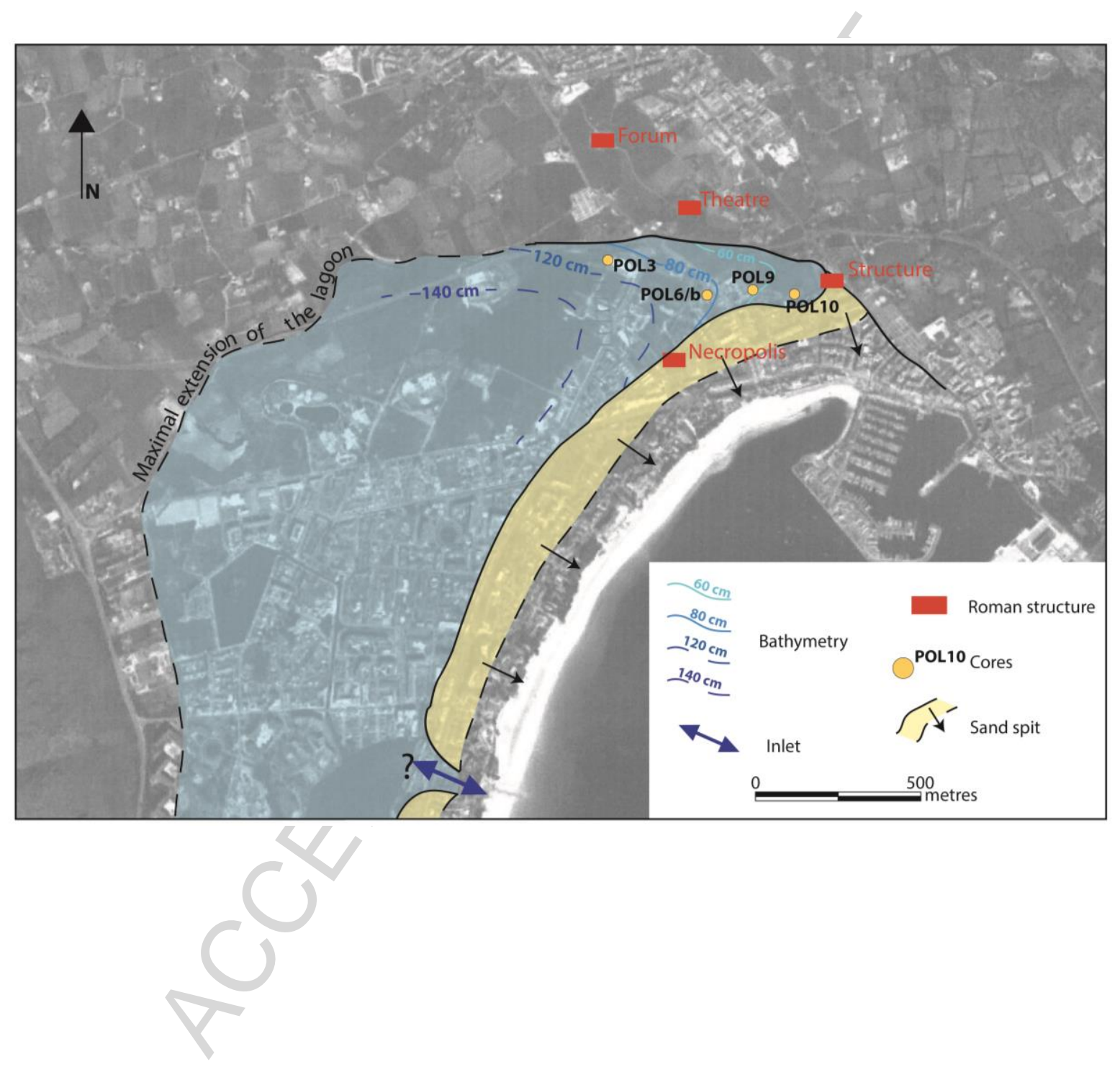


Fig.15

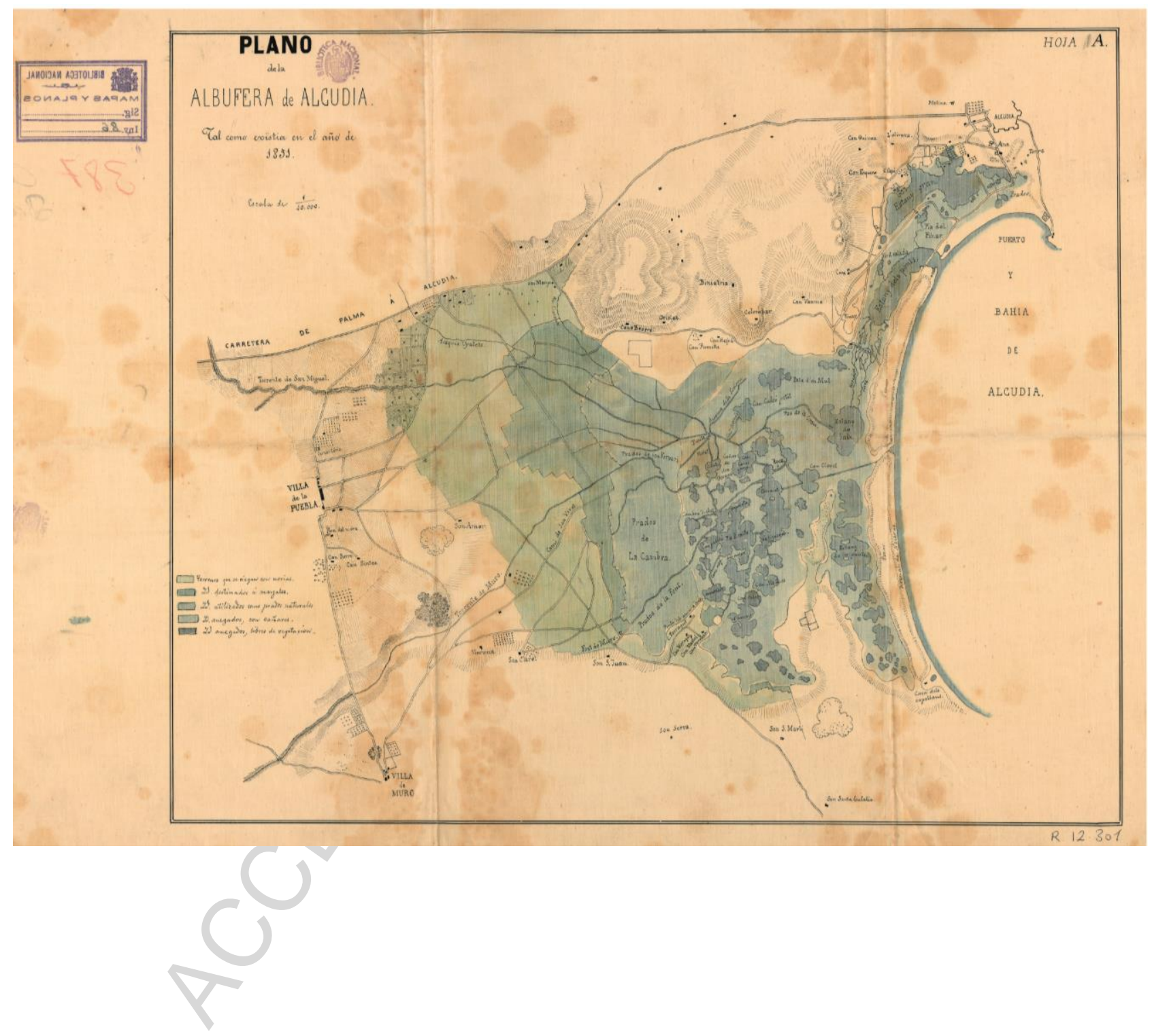


Fig.16

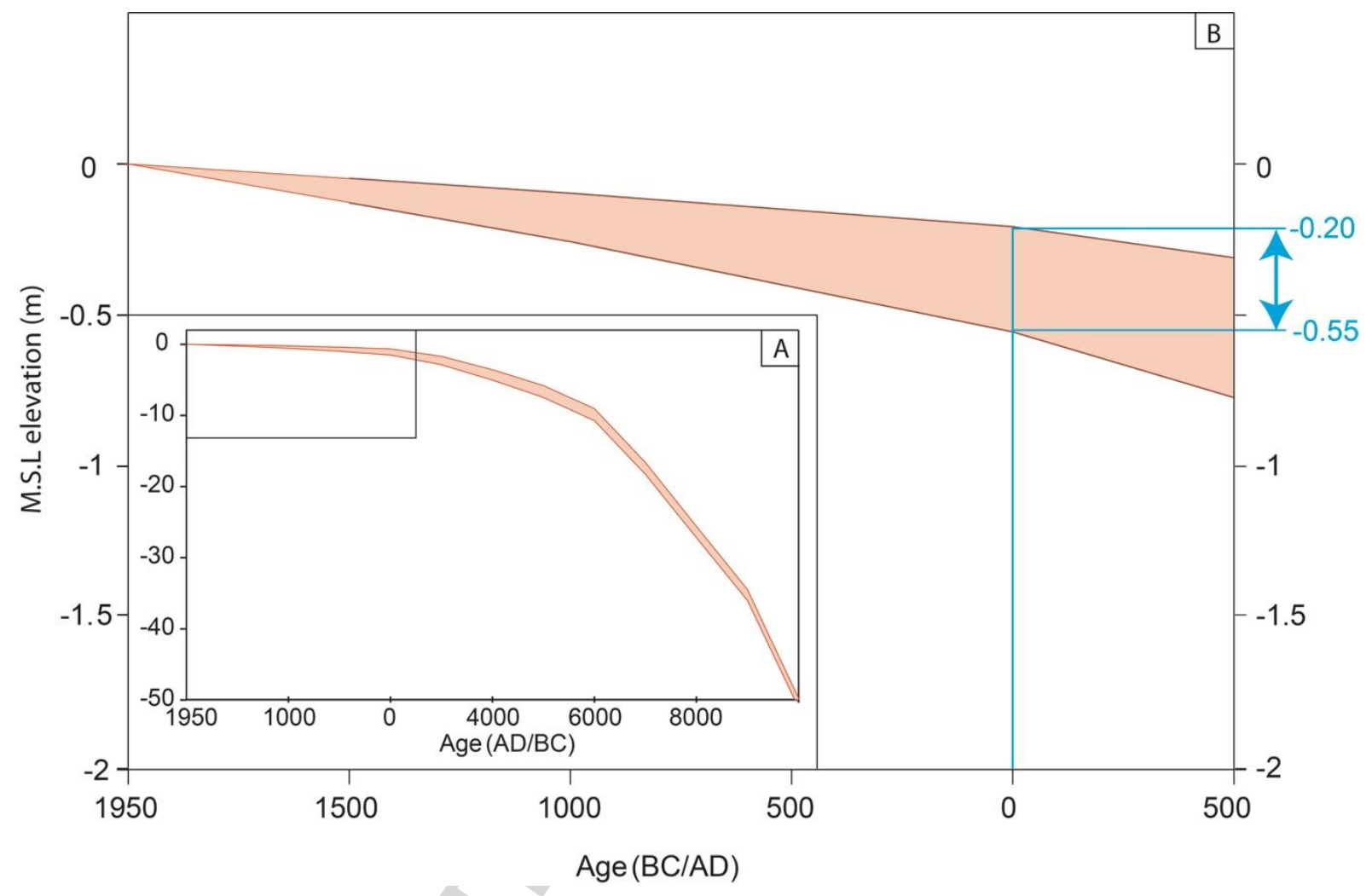


Table.1

\begin{tabular}{|c|c|c|c|c|c|c|c|c|c|}
\hline CORE & Sample & Lab number & $\mathrm{C}^{13}$ & $\begin{array}{c}\text { Depth } \\
(\mathrm{cm} \\
\text { b.s. }) \\
\end{array}$ & $\begin{array}{l}\text { Depth } \\
(\mathrm{cm} \\
\text { b.s.l. })\end{array}$ & Material & Age $C^{14}$ & $\begin{array}{c}2 \sigma B P \\
\min ; \max \end{array}$ & $\begin{array}{c}2 \sigma B C / A D \\
\min ; \max \end{array}$ \\
\hline $\mathrm{POL6/b}$ & POL6b.7 & Poz-69098 & $-8,3$ & 160 & 70 & Marine shell & $1840 \pm 30$ & $1204 ; 1421$ & 529 AD ; 746 AD \\
\hline $\mathrm{POL6/b}$ & POL6b.21 & Poz-69451 & $-7,3$ & 230 & 140 & Plant remains & $3600 \pm 30$ & $3838 ; 3978$ & $2029 \mathrm{BC} ; 1889 \mathrm{BC}$ \\
\hline $\mathrm{POL6/b}$ & POL6b.23 & Poz-69099 & 2,3 & 240 & 150 & Marine shell & & $3003-3324$ & $1375 \mathrm{BC} ; 1054 \mathrm{BC}$ \\
\hline $\mathrm{POL6/b}$ & POL6b.25 & Poz-69453 & $-13,1$ & 250 & 160 & Plant remains & $3510 \pm 30$ & $3698 ; 3865$ & $1916 \mathrm{BC}-1749 \mathrm{BC}$ \\
\hline $\mathrm{POL6/b}$ & POL6b.31 & Poz-69454 & $-9,9$ & 280 & 190 & Plant remains & $3475 \pm 35$ & $3642 ; 3838$ & $1889 \mathrm{BC} ; 1693 \mathrm{BC}$ \\
\hline $\mathrm{POL6/b}$ & POL6b.35 & Poz-69455 & $-12,3$ & 300 & 210 & Plant re & $3670 \pm 35$ & $3895 ; 4137$ & $2188 \mathrm{BC} ; 1946 \mathrm{BC}$ \\
\hline $\mathrm{POL6/b}$ & POL6b.43 & Poz-69456 & -13 & 350 & 260 & Plant remains & $3975 \pm 35$ & $4298 ; 4526$ & $2577 \mathrm{BC} ; 2349 \mathrm{BC}$ \\
\hline $\mathrm{POL6/b}$ & POL6b.53 & Poz-69457 & 3,6 & 400 & 310 & Marine shell & $0 \pm 35$ & $4941 ; 5279$ & $3330 \mathrm{BC} ; 2992 \mathrm{BC}$ \\
\hline POL3 & POL3.20 & Poz-72248 & $-4,9$ & 315 & 119 & Marine shell & $0 \pm 30$ & $858 ; 1109$ & $841 \mathrm{AD} ; 1092 \mathrm{AD}$ \\
\hline POL3 & POL3.22 & Poz-69459 & $-2,3$ & 325 & 129 & Marine shell & $5 \pm 35$ & $1424 ; 1726$ & $234 \mathrm{AD} ; 526 \mathrm{AD}$ \\
\hline POL3 & POL3.24 & Poz-72246 & $-2,3$ & 335 & 139 & Marine shell & $2425 \pm 30$ & $1849 ; 2111$ & $162 \mathrm{BC} ; 101 \mathrm{AD}$ \\
\hline POL3 & POL3.28 & Poz-69460 & $-16,8$ & 360 & 164 & plant remains & $0 \pm 30$ & $3366 ; 3470$ & $1521 \mathrm{BC} ; 1417 \mathrm{BC}$ \\
\hline POL3 & POL3.32 & Poz-69461 & $-13,3$ & 380 & 184 & & & $3409 ; 3684$ & $1735 \mathrm{BC} ; 1460 \mathrm{BC}$ \\
\hline POL3 & POL3.44 & Poz-69463 & 5,8 & 440 & 244 & & & $3674 ; 3968$ & $2019 \mathrm{BC} ; 1725 \mathrm{BC}$ \\
\hline POL9 & POL9.12 & Poz-69465 & 3 & 270 & 146 & $\mathrm{Ma}$ & +35 & $3110 ; 3392$ & $1443 \mathrm{BC} ; 1161 \mathrm{BC}$ \\
\hline POL9 & POL9.22 & Poz-69466 & 0,6 & 330 & 206 & Marin & \pm 35 & $4771 ; 5039$ & 3090 BC ; 2822 BC \\
\hline POL9 & POL9.24 & Poz-72246 & $-3,9$ & 340 & 216 & Marine shell & $5420 \pm 35$ & $5588 ; 5849$ & $3900 \mathrm{BC} ; 3639 \mathrm{BC}$ \\
\hline POL9 & POL9.29 & Poz-69467 & $-1,4$ & 375 & 251 & Marine shell & $5635 \pm 30$ & $5837 ; 6114$ & $4164 \mathrm{BC} ; 3880 \mathrm{BC}$ \\
\hline POL9 & POL9.20 & Poz-69467 & $-1,4$ & 380 & 256 & Marine shell & $5560 \pm 40$ & $5710 ; 5988$ & $4039 \mathrm{BC} ; 3761 \mathrm{BC}$ \\
\hline POL10 & POL10.7 & Poz-72249 & $-9,3$ & 230 & 50 & Freshwater snail & $1725 \pm 30$ & $1562 ; 1705$ & $245 \mathrm{AD} ; 388 \mathrm{AD}$ \\
\hline POL10 & POL10.15 & Poz-69470 & 1,4 & 300 & 120 & marine shell & $4395 \pm 35$ & $4277 ; 4604$ & $2655 \mathrm{BC} ; 2328 \mathrm{BC}$ \\
\hline POL10 & POL10.24 & Poz-69472 & $-27,6$ & 345 & 165 & & $4570 \pm 30$ & $5059 ; 5442$ & $3493 \mathrm{BC} ; 3110 \mathrm{BC}$ \\
\hline POL10 & POL10.35 & Poz-69473 & $-22,6$ & 400 & 220 & charcoal & $5060 \pm 35$ & $5728 ; 5970$ & $3958 \mathrm{BC} ; 3779 \mathrm{BC}$ \\
\hline
\end{tabular}

Table.2

\begin{tabular}{|c|c|c|c|c|c|c|}
\hline Wreck & Period & Type & $\begin{array}{c}\text { Hull weight } \\
\text { (tons) }\end{array}$ & \begin{tabular}{|c|} 
Deadweight \\
(tons)
\end{tabular} & Draught $(\mathrm{cm})$ & Reference \\
\hline Fiumicino1 & IV - V AD & Lighter / Coastal navigation & 10 & 50 & 140 & Boetto (2008) \\
\hline \multirow[t]{2}{*}{ NapoliA } & I AD & Lighter / Coastal navigation & 6,3 & 16 & 97 & Poveda (2012) \\
\hline & & Lighter / Coastal navigation & 6,3 & 21 & 113 & Poveda (2012) \\
\hline \multirow[t]{2}{*}{ NapoliC } & $I A D$ & Lighter / Coastal navigation & 6,8 & 15 & 80 & Poveda (2012) \\
\hline & & Lighter / Coastal navigation & 6,8 & 20 & 98 & Poveda (2012) \\
\hline \multirow[t]{2}{*}{ La Cavalière } & $I B C-\mid A D$ & Lighter / Coastal navigation & 5 & 18 & 80 & Charlin et al., (1978) \\
\hline & & Lighter / Coastal navigation & 5 & 25 & 105 & Charlin et al., (1978) \\
\hline Maquette & & Dolia & 9 & 30 & 105 & Carre and Roman (2008) \\
\hline
\end{tabular}


Figure 1: Location of the Roman city of Pollentia, on the eastern shore of Mallorca island. (A) Western Mediterranean basin scale. (B) Aerial photograph of Mallorca island. (C) Eastern shore of Mallorca island with Pollentia situated between the two bays and location of the Alcanada islet (source: esri). Wave rose obtained from measurements undertaken in the bay of Alcúdia in 2015 (station 2123118: Puertos del estado).

Figure 2: Main morphostructural units of Mallorca island (modified from Ginés et al., 2012).

Figure 3: Coastal geomorphology of Mallorca. (A) Serra de Tramuntana (B) platform of Migjorn (C) bay of Alcúdia (photograph Fornós).

Figure 4: Simplified geomorphological map of the bay of Alcúdia (modified from Servera et al., 2009).

Figure 5: Location of the cores drilled at the foot of the ancient city (source: ESRI and Google Earth).

Figure 6: Grain size and LOI results of the core POL6/b.

Figure 7: (A) Ostracod species and assemblages from the core POL6/b. (B) Mollusc species and assemblages from the core POL6/b.

Figure 8: Stratigraphic logs of the cores POL3, POL6/b and POL9 and results of the associated PCA.

Figure 9: Summary of the faunal and sedimentological results of the core POL6/b and PCA scores derived from faunal data.

Figure 10: Summary of the faunal and sedimentological results of the core POL3 and the PCA derived from these data.

Figure 11: Age-depth model, sedimentation rates and water column reconstructed for the core POL3.

Figure 12: Grain size and LOI results of the core POL10. 
Figure 13: (A) Ostracod species and assemblages of the core POL10. (B) Molluscs species and assemblages of the core POL10.

Figure 14: Palaeogeographical reconstruction of the lagoon 2000 years ago.

Figure 15: Historical map representing the southern shore of Alcúdia (1851). Biblioteca Nacional (Madrid).

Figure 16: Model of RSL rise in Mallorca since 10000 cal. yr. BC (A). Zoom on RSL rise in Mallorca since $500 \mathrm{cal}$. yr. BC. The values on the right indicate the range of the estimated sea-level position ($0,35 \mathrm{~cm}+/-15 \mathrm{~cm})$.

Table 1: AMS- ${ }^{14} \mathrm{C}$ data. The radiocarbon ages are expressed in calibrated years $\mathrm{BP}$ and $\mathrm{BC}$ at the $95 \%$ confidence level $(2 \sigma)$. b.s. $=$ below surface, b.s.l. $=$ below present mean sea level. Calibration using Calib 7.1. (Stuiver and Reimer, 1993) and the IntCal13 curve (Reimer et al., 2013).

Table 2: Dimensions of several Roman ships-wreck discovered in the Mediterranean. 


\section{Highlights}

A lagoon was situated near the city of Pollentia during Roman times.

This lagoon probably hosted one of the city's harbours.

Chronostratigraphy supports a harbour foundation between $1^{\text {st }} \mathrm{c}$. BC and the $1^{\text {st }} \mathrm{c}$. AD.

A chronological gap of 1000 years suggests dredging. 